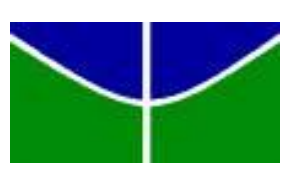

Universidade de Brasília - UnB

Faculdade de Economia, Administração, Contabilidade e Ciência da Informação e Documentação - FACE

Departamento de Ciência da Informação e Documentação - CID

Restauração de documentos com suporte em papel: um estudo de caso no Centro de Documentação da Universidade de Brasília.

Brasília

Dezembro/2009 


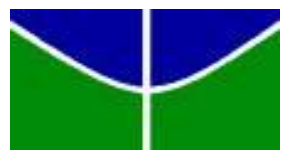

Universidade de Brasília - UnB

Faculdade de Economia, Administração, Contabilidade e Ciência da Informação e Documentação - FACE

Departamento de Ciência da Informação e Documentação - CID

\section{Restauração de documentos com suporte em papel: um estudo de caso no Centro de Documentação da Universidade de Brasília}

Gabriella da Silva Motta Barros

Monografia apresentada ao Departamento de Ciência da Informação e Documentação da Universidade de Brasília como requisito parcial para a obtenção do grau de bacharel em Biblioteconomia.

Orientadora: Prof.a Dr.a Miriam Paula Manini

\section{Brasília}

Dezembro/2009 
Título: Restauração de documentos com suporte em papel: um estudo de caso no Centro de Documentação da Universidade de Brasília

Aluna: Gabriella da Silva Motta Barros

Monografia apresentada ao Departamento de Ciência da Informação e Documentação da Universidade de Brasília, como parte dos requisitos para obtenção do grau de bacharel em biblioteconomia.

Brasília, 10 de dezembro de 2009.

Aprovada por:

Miriam Paula Manini - Orientadora

Professora do Departamento de Ciência da Informação e Documentação (CID) Doutora em Ciências da Comunicação e Especialista em Conservação e Preservação Fotográfica

\section{Dulce Maria Baptista - Membro}

Professora do Departamento de Ciência da Informação e Documentação (CID) Doutora em Ciência da Informação

\section{Silmara Kuster de Paula Carvalho - Membro}

Professora do Departamento de Ciência da Informação e Documentação (CID) Mestre em Tecnologia e Especialista em Conservação de Obras sobre Papel 
Ao meu querido pai Vladimir, que com dedicação, paciência e amor, sempre me guia, ensina e acolhe. 


\section{AGRADECIMENTOS}

À restauradora e chefe do Laboratório de Conservação e Restauração de Documentos (LACOR) do Superior Tribunal de Justiça, Maria Solange de Brito Silva Meira, que me apresentou à sua profissão. Seus ensinamentos e incentivos foram decisivos para minha formação e graças a ela e aos colegas do LACOR eu estou conseguindo me realizar profissionalmente.

Aos colegas do Centro de Documentação da Universidade de Brasília (CEDOC), que me auxiliaram na construção desse trabalho, especialmente à encadernadora Rosana.

À professora Miriam Manini, exemplo de profissional dedicada, pelo apoio e orientação.

Aos colegas de curso que compartilharam comigo tantos momentos felizes e construtivos, especialmente Paula e Vanessa.

Aos meus tios, primos, avós, irmãos e à minha mãe Giselle, que foram fundamentais para o alcance dessa vitória e de tantas outras. 
"Um país se faz com homens e livros."

(Monteiro Lobato) 


\section{RESUMO}

O trabalho aborda um estudo de caso no laboratório de restauração de documentos gráficos do Centro de Documentação da Universidade de Brasília. Apresenta a história do papel e seus fatores de degradação. Mostra o conceito de restauração, conservação e preservação, com o intuito de fundamentar seus princípios e importância. Finalmente, apresenta como exemplo a restauração completa de um livro pelo laboratório do CEDOC/UnB visando a analisar as técnicas de restauro realizadas no miolo.

Palavras-chave: restauração; conservação; preservação; suporte em papel. 


\begin{abstract}
The paper addresses a case study in the laboratory of restoration of graphic material of the Documentation Center of the University of Brasilia (CEDOC/UnB). Presents the history of the paper and factors of degradation. Shows the concept of restoration, conservation and preservation, in order to justify their importance and principles. Finally, it presents as an example the complete restoration of a book by the laboratory of CEDOC/UnB aiming to analyze the techniques of restoration carried out.
\end{abstract}

Keywords: restoration, conservation, preservation, paper. 


\section{LISTA DE FIGURAS}

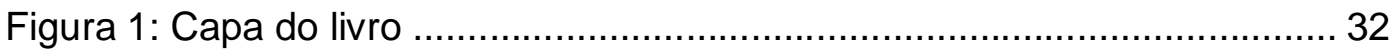

Figura 2: Lombada solta ............................................................ 32

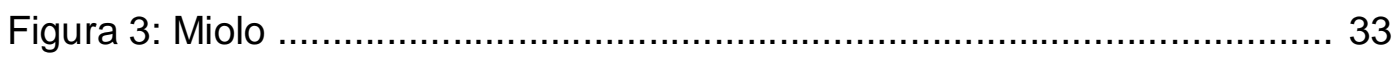

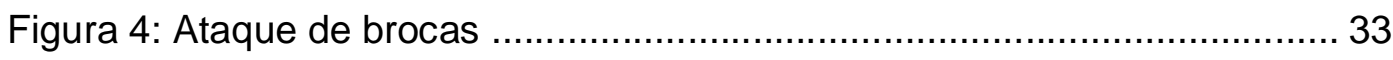

Figura 5: Costura e adesivo ............................................................ 34

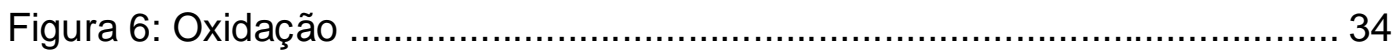

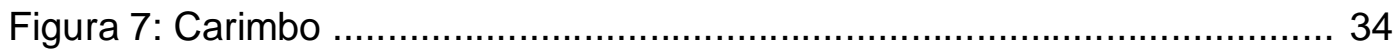

Figura 8: Numeração do livro ................................................................... 35

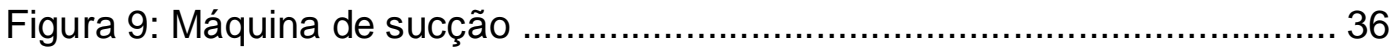

Figura 10: Higienização com trincha ................................................... 36

Figura 11: Ponto de ferrugem ........................................................ 37

Figura 12: Retirada do ponto de ferrugem com bisturi .............................. 37

Figura 13: Antes da aplicação do pó de borracha ..................................... 38

Figura 14: Durante a aplicação do pó de borracha .................................... 38

Figura 15: Após a aplicação do pó de borracha ........................................ 38

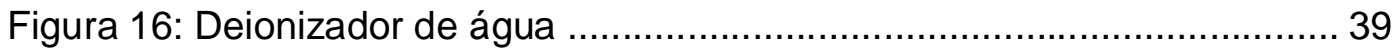

Figura 17: Cubas para banho ............................................................ 40

Figura 18: Folhas entre crepes ......................................................... 41

Figura 19: Cuba 1 após a imersão das folhas ......................................... 41

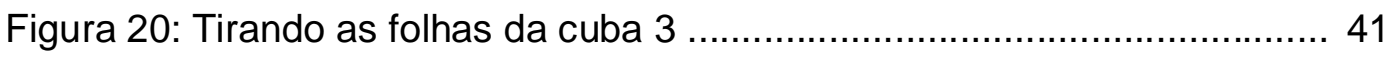

Figura 21: Secadora .................................................................... 41

Figura 22: Preparo para a remoção …................................................... 43

Figura 23: Camada de talco neutro ................................................... 43

Figura 24: Aplicação de Acetato de etila .................................................... 44

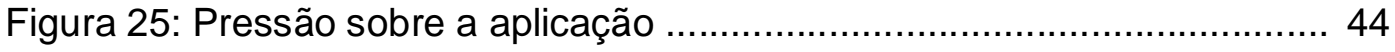

Figura 26: Resultado após quatro aplicações ............................................ 44

Figura 27: Peso das folhas saudáveis .................................................. 45

Figura 28: Peso das folhas a serem processadas ................................... 46

Figura 29: Papel picotado ................................................................. 47

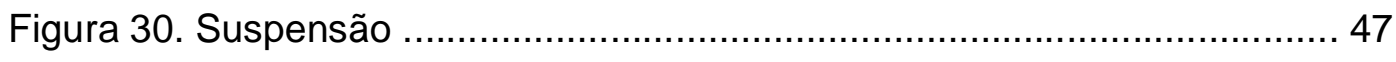

Figura 31: Maquina obturadora de papel (MOP) ................................... 47 
Figura 32: Folhas dispostas na MOP .47

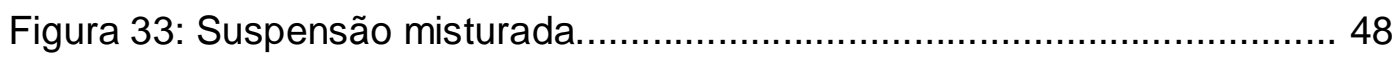

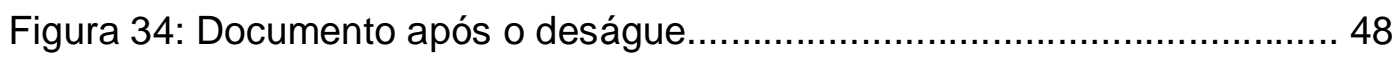

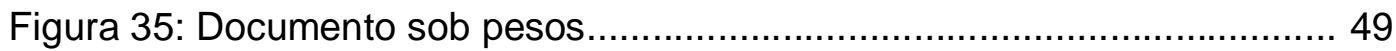

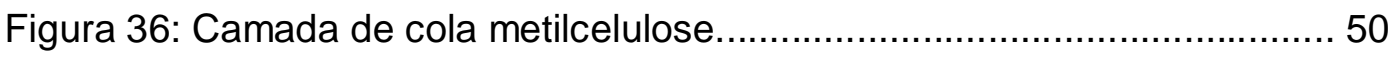

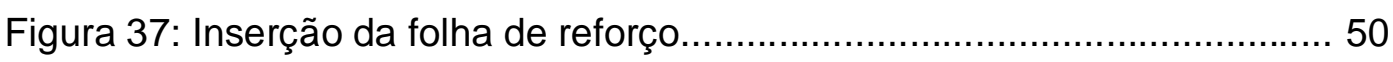

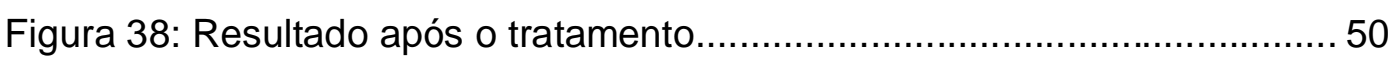

Figura 39: Cuba com água deionizada e chá preto....................................... 51

Figura 40: Papel japonês branco entre telas de nylon........................................51

Figura 41: Papel japonês imerso em água com chá....................................... 52

Figura 42: Papel japonês tingido............................................................. 52

Figura 43: Corte no papel japonês com agulha............................................ 53

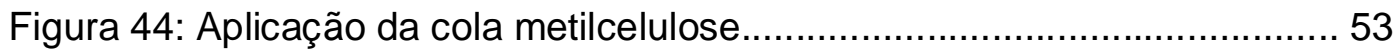

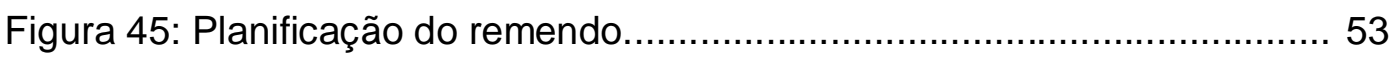

Figura 46: Papel japonês umedecido sobre placa de papel acetato................ 54

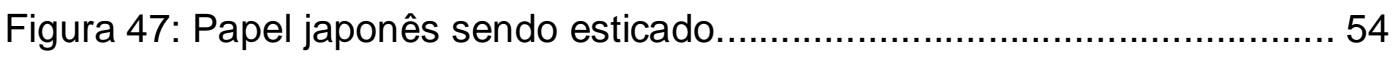

Figura 48: Aplicação de metilcelulose sobre o papel japonês.......................... 55

Figura 49: Velatura sob tela de nylon e mata-borrão....................................... 55

Figura 50: Aplicação de cola metilceluse na área a ser enxertada................... 56

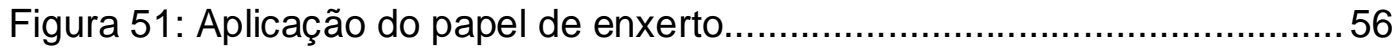

Figura 52: Desbastamento do papel de enxerto............................................ 56

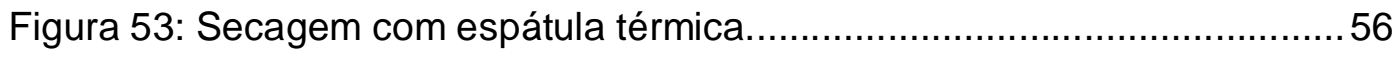

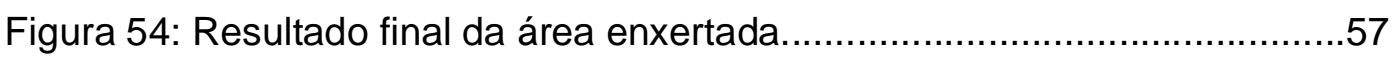

Figura 55: Polpa de papel com cola metilcelulose........................................... 57

Figura 56: Furos ocasionados por ataque de brocas..................................... 57

Figura 57: Aplicação de polpa de papel em furos........................................... 58

Figura 58: Espátula fixando a aplicação de polpa............................................58

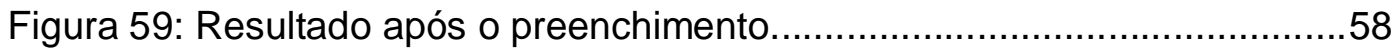

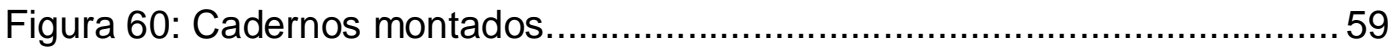

Figura 61: Costura com agulha e linha de algodão.........................................59

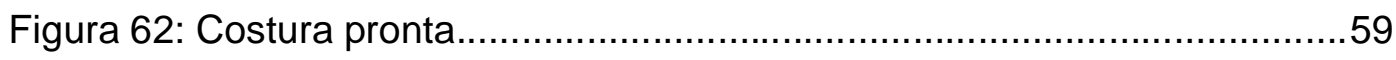

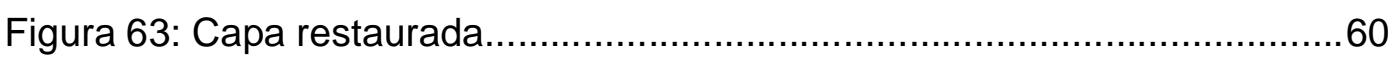

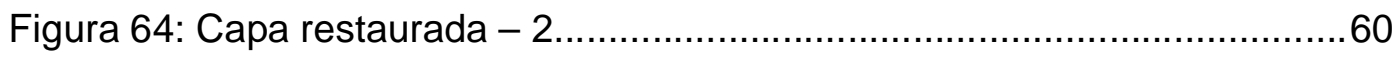

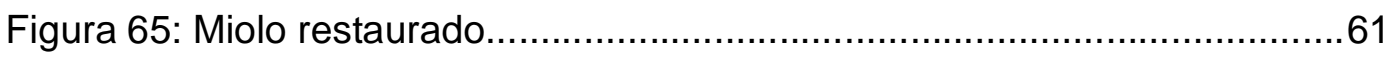




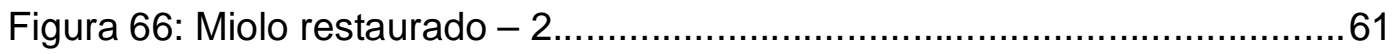

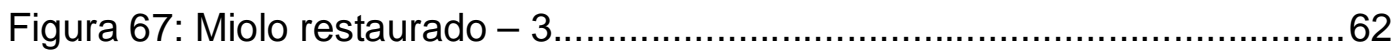

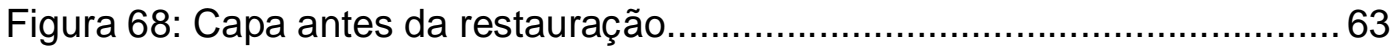

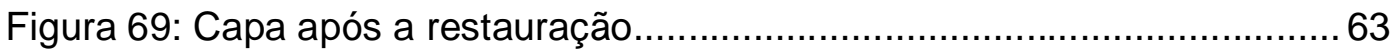

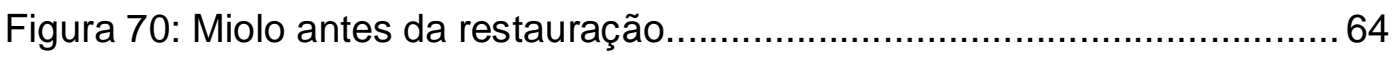

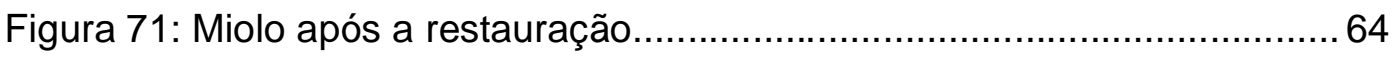


1. INTRODUCÃO

2. JUSTIFICATIVA

3. PROBLEMA

4. OBJETIVOS:

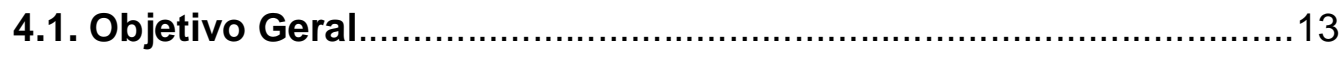

4.2. Objetivos Específicos.............................................................. 13

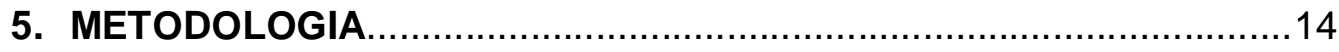

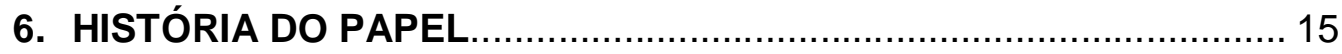

7. FATORES DE DEGRADAÇAO DO PAPEL..................................... 17

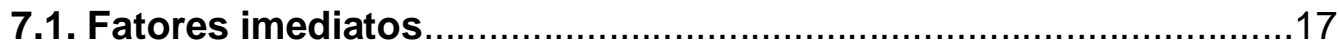

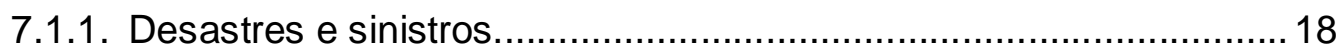

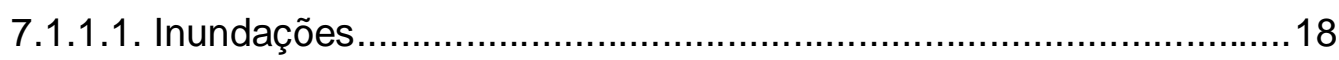

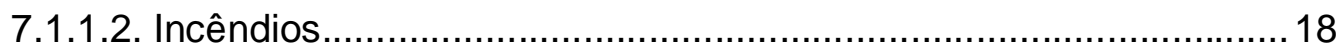

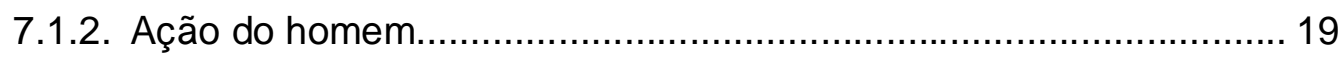

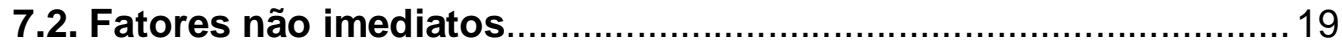

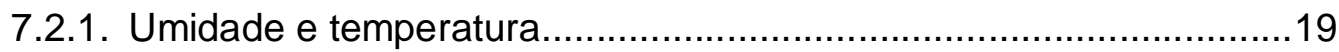

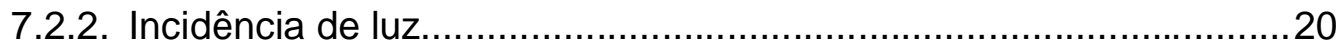

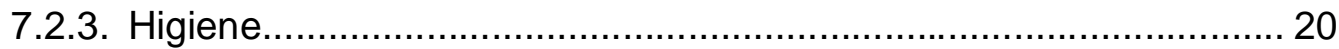

8. CONCEITOS

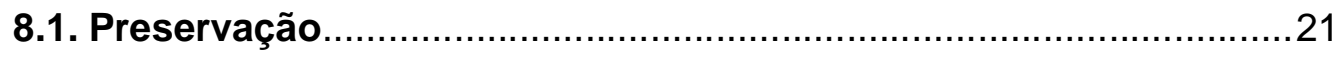

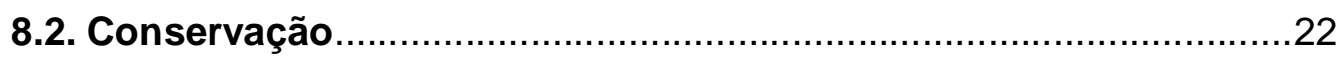

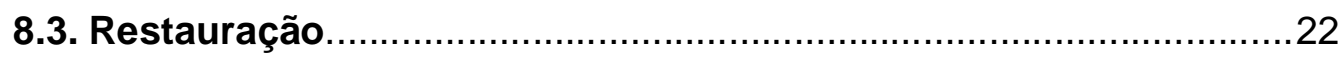

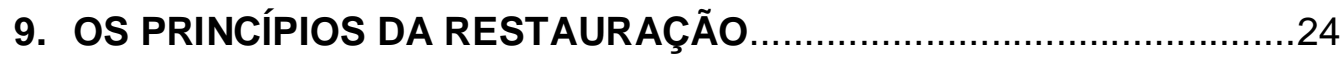

10.ESTUDO DE CASO

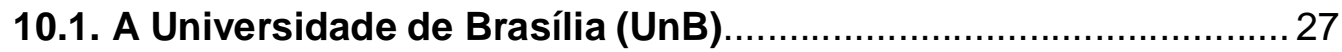

10.1.1. O Departamento de Ciência da Informação e

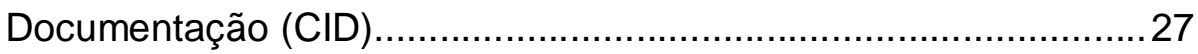

10.1.2. O Centro de Documentação da UnB (CEDOC).............................. 29

10.1.2.1. O Laboratório de Restauração do CEDOC .....................................30

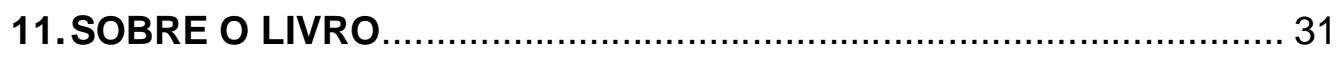

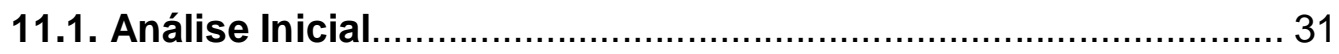




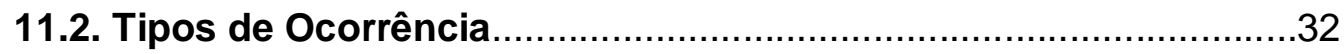

11.2.1. Сapa

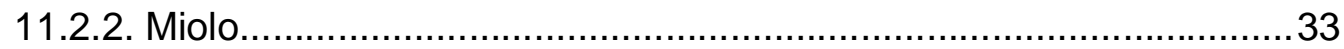

12. TÉCNICAS DE RESTAURO REALIZADAS NO MIOLO ..........................35

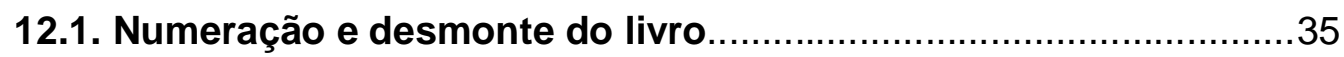

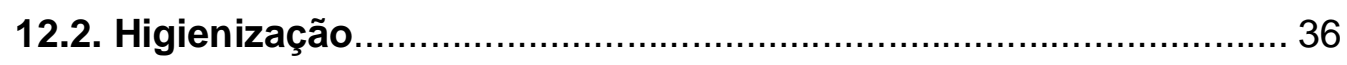

12.2.1. Higienização com trincha folha por folha...................................... 37

12.2.2. Retirada da sujidade e pontos de ferrugem com bisturi....................37

12.2.3. Limpeza com aplicação de pó de borracha.....................................39

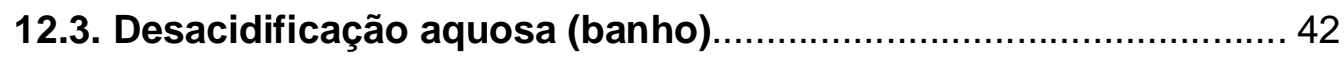

12.4. Remoção de marca ocasionada por fita adesiva.......................... 44

12.5. Reintegração mecânica com reforço............................................ 45

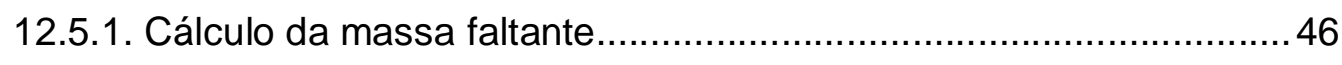

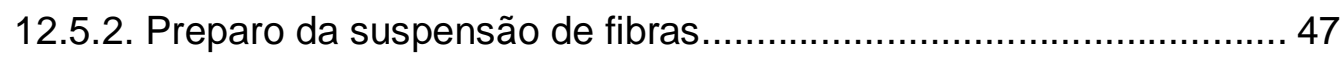

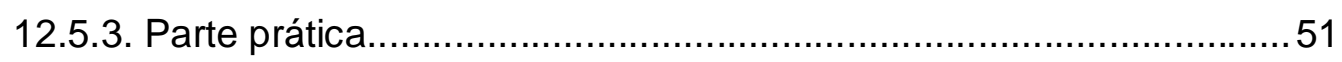

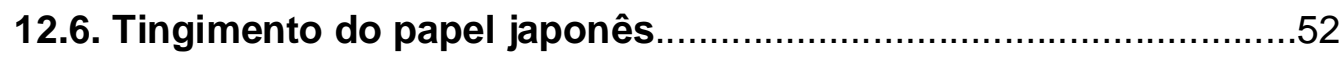

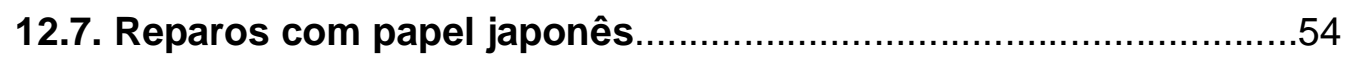

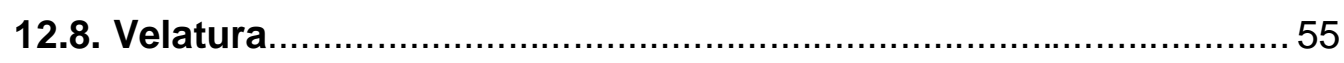

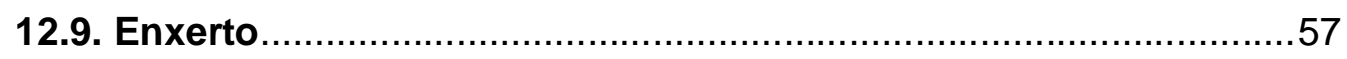

12.10. Preenchimento de furos com polpa de papel.............................59

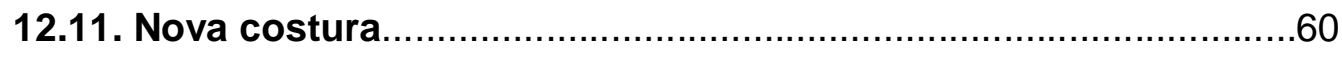

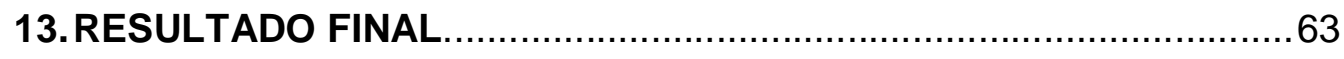

14.CONCLUSÃO 


\section{INTRODUÇÃO}

"A informação é um conhecimento inscrito (registrado) em forma escrita (impressa ou digital, oral ou audiovisual), em um suporte" (LE COADIC, 2004, p. 4). Tudo que se produz intelectualmente só é difundido e conhecido quando se torna físico, palpável, visível ou sonoro. Um suporte informacional é feito para comportar informações e a informação só tem importância e reconhecimento quando concretizada em um suporte, seja ele digital ou não. Sendo a informação um elemento básico para a evolução social, intelectual e histórica, pode-se ter idéia da amplitude e da importância que um suporte representa para a humanidade.

Para que um material seja bem conservado e, consequentemente, a sua informação, é preciso adotar técnicas específicas de tratamento para cada tipo de suporte; o mesmo pode ser dito a respeito da restauração dos vários tipos de materiais. Uma boa política de conservação e restauração de documentos só é possível quando se tem conhecimento a respeito da estrutura do suporte e seus fatores de degradação.

São diversos os tipos de suporte de informação, mas neste trabalho será abordado especificamente o tradicional papel. 


\section{JUSTIFICATIVA}

Mesmo com o avanço tecnológico, o papel continua sendo um suporte informacional muito usado. Grande parte dos registros documentais se encontra neste tipo de suporte; por isso, o profissional da área de documentação necessita saber tanto as peculiaridades de sua conservação quanto de sua restauração e sua importância documental.

\section{PROBLEMA}

Quais são os fatores que podem degradar documentos e livros com suporte em papel? Qual é o conceito de restauração, conservação e preservação? Quais são os princípios da restauração? Quais são as técnicas de restauração utilizadas, em documentos com suporte em papel, pelo Centro de Documentação da Universidade de Brasília?

\section{OBJETIVOS:}

\subsection{Objetivo Geral}

Conhecer os fatores de degradação do papel e as técnicas de restauração adotadas pelo laboratório de restauração de documentos gráficos do Centro de Documentação da Universidade de Brasília.

\subsection{Objetivos Específicos}

- Argumentar sobre a importância da restauração de documentos;

- Fazer uma análise histórica da evolução do papel;

- Identificar tipos e fatores de degradação do papel;

- Defender os princípios da conservação e da restauração; 
- Demonstrar técnicas de conservação e restauração adotadas pelo CEDOC/UnB.

\section{METODOLOGIA}

Primeiramente foi feita uma pesquisa bibliografia buscando uma literatura que abordasse os temas preservação, conservação, restauração, fatores de degradação e história do papel. $O$ trabalho prioriza a parte prática da restauração de documentos com suporte em papel, mostrando passo a passo todo o processo de restauração de um livro.

Em segundo lugar, foi escolhido um livro do acervo de obras raras da Biblioteca Central da Universidade de Brasília que necessitava ser restaurado. A restauração foi documentada e conduzida pela própria autora, que buscou através de fotos - descrever tudo que foi feito para restaurar o livro. 


\section{HISTÓRIA DO PAPEL}

A pedra, a madeira e a placa de argila foram os primeiros suportes de informação. Depois surgiu o papiro, planta de caule frágil na qual só se podia escrever de um lado. Em seguida foi inventado o pergaminho, que era obtido do couro de animais, como porcos, gados e carneiros; nele se podia escrever de ambos os lados. Em seguida, o papel foi inventado.

Segundo Ingrid Beck o papel mais antigo de que se tem notícia foi encontrado na Muralha da China, no ano 100 d.C. Porém Jayme Spinelli afirma que o papel só foi desenvolvido no ano 105 d.C. e em 2006 arqueólogos chineses descobriram um pedaço de papel com inscrições que poderia ser 0 mais antigo da história, pois data do século I AC. Tendo em vista a variedade de datas atribuídas ao nascimento do papel mais antigo do mundo percebe-se que não existe um consenso sobre essa data e ainda tem muito o que se descobrir.

A matéria-prima básica do papel eram restos de seda e de tecidos de algodão, denominado papel trapo, que é de altíssima resistência e durabilidade. Na fabricação desse papel os tecidos molhados eram macerados até que ficassem reduzidos a uma massa de fibras, que depois era despejada sobre uma malha de bambu. Quando a massa secava, uma fina camada de fibras entrelaçadas ficava depositada sobre o bambu: a isto se denominou papel.

A manufatura do papel permaneceu em segredo até o século VIII, quando, com a expansão árabe, foi levada à Europa. Conforme o papel ia sendo conhecido, outros tipos de fibras passaram a ser adicionadas em sua receita (como as do bambu, do cânhamo e da amoreira) e outras formas de tratamento em seu processo básico de manufatura foram adotados (como a substituição da malha de bambu por uma tela de fios metálicos). Para que o papel se tornasse uniforme, mais resistente e impermeável, começou-se a passar em sua superfície a goma de amido, resinas vegetais e cola animal (gelatina), esse processo é denominado encolagem.

A partir do século XIV, os artesãos que fabricavam papel passaram a deixar sua marca d'água registrada na folha para identificar seus produtos. 
Para fazer as filigranas era usado o próprio nome do artesão ou um símbolo qualquer, que era gravado por um modelo de arame muito fino preso à malha.

Até o século XVIII a técnica de maceração de papel era baseada num sistema de pilão, em que martelos movidos pela força da água ou do vento transformavam os trapos molhados em uma pasta de fibras. Depois se desenvolveu a holandesa, máquina que possui um cilindro cuja rotação movimenta o trapo molhado ate formar a pasta.

Com a invenção da imprensa e o aumento da produção de papel, sua matéria-prima se tornava cada vez mais escassa. Isso forçou experiências a fim de se conseguir outro tipo de matéria-prima para a fabricação de papel. $O$ desejo de se descobrir um outro material que substituísse o tecido na feitura de papel foi realizado na segunda metade do século XIX, quando se conseguiu fazer papel com fibras de madeira. Esse avanço foi determinante para a produção em grande escala de papéis feitos de madeira, por ser um material muito mais barato que o tecido.

O grande problema encontrado nos papéis feito com esse novo tipo de matéria-prima é sua baixa resistência, fragilidade e durabilidade. As fibras da madeira são muito curtas e se entrelaçam com dificuldade, fazendo com que o papel fique frágil e rasgue com facilidade; além disso, ele retém grande quantidade de substância resinosa (lignina), que se torna um agressor com o passar do tempo, tornando o papel ácido e, consequentemente, mais frágil e amarelado, podendo até transferir essa acidez para outro documento que esteja em contato direto com ele. Até o processo de extração de lignina deixa resíduos nocivos, e a encolagem, que é feita a base de alúmen - resina - é ácida e prejudica o papel.

Percebe-se que, com a mudança de matéria-prima na fabricação do papel, aumentou a quantidade em detrimento da qualidade. O papel trapo possuía mais resistência e durabilidade que o papel feito de madeira, mas era mais caro. Porém, ainda é possível seguir os métodos tradicionais antigos e obter papéis bons como os de antigamente.

Atualmente existe um leque enorme de tipos de papel, desde os frágeis e ácidos (como o papel jornal) até os resistentes e livres de acidez. 


\section{FATORES DE DEGRADAÇAO DO PAPEL}

O papel é um suporte muito utilizado até hoje. Nos arquivos e nas bibliotecas a preocupação com a conservação de obras e documentos em papel é grande e por isso se torna necessário conhecer os fatores que agem contra a longevidade desse suporte tão difundido.

Quando um documento se encontra em um estado de deterioração considerável já se pode dizer que houve alguma ação destruidora ou não houve alguma ação protetora. Dessa forma, conclui-se que geralmente são dois casos que acarretam o estrago dos documentos: 1) os livros são destruídos; ou 2) "abandonados à ação dos séculos, que dele(s) se apoderam como se fosse uma coisa que lhes pertencesse, para corroê-lo pouco a pouco" (VIOLLET-LE-DUC, 2000, p. 30).

O primeiro caso diz respeito a ações que são detonadas em um curto espaço de tempo, como desastres, sinistros e destruição por parte dos homens.

O segundo caso se refere a fatores que agem a partir da combinação do descaso com a passagem de tempo, como condições inadequadas de temperatura, umidade relativa e higiene, dentre outros, que acabam favorecendo a proliferação de roedores, insetos e microorganismos.

De acordo com essa visão, os fatores de degradação serão divididos, neste trabalho, em imediatos e não imediatos.

\subsection{Fatores imediatos}

Os fatores imediatos são os desastres, sinistros e a ação do homem. Eles são devastadores e de difícil previsão. Porém, é possível montar uma política de preservação voltada para eles.

\subsubsection{Desastres e sinistros}

Dentre os desastres e sinistros mais frequentes em bibliotecas estão as inundações e os incêndios. Seus estragos, na maioria das vezes, são 
irreversíveis e ao longo da história são vários os documentos raros e valiosos que foram destruídos por esses fatores. Um exemplo da destruição que a água pode provocar foram as inundações de 1966 em Florença que danificou mais de dois milhões de manuscritos. Em 1986 a Biblioteca Central de Los Angeles sofreu dois incêndios que resultaram na perda de 400000 volumes. $\mathrm{Na}$ Biblioteca da Academia das Ciências em S. Petersburgo em 1988 um incêndio provocou a perda de 300000 livros.

\subsubsection{Inundações}

As inundações podem ser ocasionadas por inadequação de instalações hidráulicas ou agentes da natureza: "as inundações ocorridas em qualquer intensidade sempre provocam, com frequência, (sic) grandes danos aos livros e documentos." (SPINELLI JUNIOR, 1997, p. 36). Um dos mais graves danos imediatos que podem acontecer com os documentos molhados é o surgimento e a proliferação de fungos. Seus danos podem ser revertidos caso aconteça um socorro rápido e eficaz.

Atualmente existem cinco formas de secagem de livros que são: secagem ao ar (indicado para livros moderadamente molhados); desumidificação (desumidificadores são introduzidos no ambiente); secagem por congelamento (livros são secos em uma câmara frigorífica); secagem térmica a vácuo (livros são secos em uma câmara de secagem térmica a vácuo); secagem por congelamento a vácuo (livros são secos através do processo químico de sublimação).

\subsubsection{Incêndios}

Incêndios podem ser criminosos, naturais ou acontecer em decorrência de curtos-circuitos nos sistemas de eletricidade. Seus danos são praticamente irreversíveis, por isso exige uma política de proteção eficaz e uma boa tática de socorro ao acervo caso aconteça. Para evitar que um incêndio ocorra ou para minimizar seus estragos é necessário que se faça um programa de proteção, com a instalação de equipamentos de detecção de fumaça, controle de fogo e o auxílio de brigadas de incêndio. 


\subsubsection{Ação do homem}

O homem pode acarretar degradação ao documento caso o manuseie de forma incorreta, rabisque, insira adesivo, corte, etc. Outro fator, mais triste e que infelizmente acontece muito em bibliotecas e arquivos, é o furto de livros e documentos, o que ocasiona perda total de informação caso o exemplar seja único. Então se deve procurar educar o usuário e adotar medidas de segurança anti-furto.

\subsection{Fatores não imediatos}

Os fatores não imediatos são condições inadequadas de umidade relativa, de temperatura e de higiene, além da ocorrência de incidência de luz sobre a documentação. Esses fatores, combinados com a passagem de tempo (que pode ser curta ou longa), acabam oferecendo um ambiente propício para a proliferação de insetos, roedores e microorganismos, ou ativando fatores intrínsecos de deterioração do papel, como sua acidificação e esfarelamento.

Esses fatores são de fácil previsão e profilaxia; porém, se não forem controlados a tempo, serão devastadores tanto quanto os fatores imediatos.

\subsubsection{Umidade e temperatura}

Os fatores ambientais de umidade relativa e temperatura, quando inadequados, contribuem bastante para a degradação do documento, pois "suas variações submetem os suportes gráficos a movimentos de estiramento e de contração (o que acontece devido à grande afinidade entre a celulose e a água), que enfraquece o papel" (SPINELLI JUNIOR, 1997, p. 23). Além disso, esses fatores ambientais são responsáveis pelo desenvolvimento de microorganismos e infestação por insetos e roedores.

Alguns documentos estão escritos em tinta ferrogálica, que é composta por metais e pode provocar a corrosão irreversível do papel. Uma condição inadequada de umidade relativa pode acelerar o processo de oxidação dessa 
tinta, destruindo assim o suporte e a informação nele contida. Os resíduos químicos deixados pelo processamento de papéis feitos de madeira também podem ser ativados se a temperatura e a umidade relativa não forem controladas, ocasionando manchas, pontos de ferrugem e de acidez no papel.

É recomendado que a temperatura do ambiente seja de $21^{\circ} \mathrm{C}$ ou menos e a umidade relativa do ar esteja entre um mínimo de $30 \%$ e um máximo de $50 \%$.

\subsubsection{Incidência de luz}

Tanto a luz artificial quanto a natural são fortes geradoras de radiação ultravioleta (UV), e a exposição do documento à luz é nociva pois "é capaz de fragilizar os materiais constitutivos dos documentos, introduzindo um processo de envelhecimento acelerado." (SPINELLI JUNIOR, 1997, p. 28). A radiação infravermelha, também presente na luz, emite muito calor e por isso se torna prejudicial ao acervo tendo em vista que a alta temperatura contribui para a deterioração do papel. A luz também contribui para os danos das tintas, por isso a exposição dos acervos à luz deve ser controlada.

\subsubsection{Higiene}

As sujidades que se acumulam no acervo podem vir do ar ou da falta de cuidado dos usuários, que podem manipular alimentos perto dos documentos. Essas sujidades podem favorecer a propagação de insetos, roedores e microorganismos, além de causar manchas e oxidação no documento. Assim, deve-se adotar a prática de higienização periódica, que visa, além da eliminação das sujidades, ao estabelecimento de uma frequência na identificação de qualquer tipo de ataque. Também é importante educar o usuário e policiá-lo, a fim de evitar que descumpra as normas de higiene da instituição. 


\section{CONCEITOS}

Quando se pensa em restauração, geralmente temos a idéia de reconstrução, reintegração, reparação, restituição, tornar algo reutilizável e reabilitado. Esses termos podem ser aplicados nas inúmeras áreas da atividade humana (industrial, manufatureira, artística, documental, biológica, física, etc.), fazendo referência a objetos de seus estudos que passaram por um processo de intervenção específico que se chama restauro. Porém, o que interessa para esse trabalho é o conceito de restauração ligado ao contexto documental relacionado com o papel.

Devido à ampla relação entre os termos restauração, conservação e preservação de documentos, torna-se necessário conceituar cada um deles para que posteriormente se tornem mais claros ao entendimento do trabalho.

\subsection{Preservação}

- "Função arquivística destinada a assegurar as atividades de acondicionamento, armazenamento, conservação e restauração de documentos." (CAMARGO e BELLOTTO 1996, p.61);

- "É um conjunto de medidas e estratégias de ordem administrativa, política e operacional que contribuem direta ou indiretamente para a preservação da integridade dos materiais." (CASSARES, Norma, 2000, p.15);

- "Medidas empreendidas com a finalidade de proteger, cuidar, manter e reparar ou restaurar os documentos." (CUNHA, Murilo, 2008, p. 290).

A preservação é um termo amplo. Ela engloba conservação, restauração e o que se refere à gestão de uma política de manutenção de um acervo. Para Solange Zúñiga (2002, p. 73), “a preservação é entendida de forma extremamente abrangente, compreendendo todas as ações desenvolvidas pela instituição visando (sic) retardar a deterioração e possibilitar pleno uso a todos os documentos sob sua custodia." 


\subsection{Conservação}

- "Conjunto de procedimentos e medidas destinadas a assegurar a proteção física dos arquivos contra agentes de deterioração." (CAMARGO e BELLOTTO 1996, p.18);

- "É um conjunto de ações estabilizadoras que visam (sic) desacelerar o processo de degradação de documentos ou objetos, por meio de controle ambiental e de tratamentos específicos (higienização, reparos e acondicionamento)." (CASSARES, Norma, 2000, p.15);

- "Conjunto de medidas empreendidas com a finalidade de preservar e restaurar documentos." (CUNHA, Murilo, 2008, p. 103).

Tomando como base os conceitos acima, pode-se dizer que a conservação visa a manter a integridade dos arquivos e a estagnar os efeitos degradantes causados por diversos agentes. A conservação é um termo amplo que engloba a restauração. $O$ termo usado por Solange Zúñiga é conservação preventiva, ou seja, "o conjunto de ações que visam (sic) prevenir os danos sofridos pelo acervo como um todo, minimizando a deterioração dos documentos." (ZÚÑIGA, 2002, p. 73). Ela ainda afirma que é uma ação interventiva que age sobre um conjunto de documentos.

\subsection{Restauração}

- "Conjunto de procedimentos específicos para recuperação e reforço de documentos deteriorados e danificados." (CAMARGO e BELLOTTO, 1996, p. 67);

- "É um conjunto de medidas que objetivam a estabilização ou a reversão de danos físicos ou químicos adquiridos pelo documento ao longo do tempo e do uso, intervindo de modo a não comprometer sua integridade e seu caráter histórico." (CASSARES, Norma, 2000, p. 15); 
- "Aplicação de técnicas para reparar documentos danificados, com a intenção de contribuir para a sua preservação." (CUNHA, Murilo, 2008, p. 323).

A partir desses conceitos, conclui-se que a restauração é 0 ato de recompor o suporte de um documento danificado, também se preocupando com agentes de deterioração que se encontram ativos no suporte, procurando reverter ou estabilizar os estragos. Solange Zúñiga usa o termo conservação/restauração para esse tipo de intervenção e o define como "o exame do documento, seu tratamento e a documentação desse tratamento." (ZÚÑIGA, 2002, p. 73). Segundo a autora, é uma ação interventiva que age sobre um item individual.

Conclui-se que restauração é 0 ato de recompor um documento deteriorado e the devolver sua integridade física para que possa ser utilizado novamente; age sobre um documento individualmente. Já a conservação, que engloba a restauração, preocupa-se também com o controle de agentes de deterioração dos documentos, buscando prolongar a vida útil dos mesmos, agindo sobre um conjunto deles. Por fim, a preservação, que engloba a restauração e a conservação, visa a uma política de preservação dos documentos e age direta e indiretamente sobre o acervo.

Assim, pode-se dizer que o presente trabalho estuda a restauração de um documento que se encontrava em um estado degradante, ou seja, que não sofreu uma boa política de preservação e conservação e necessitava ser revitalizado. 


\section{OS PRINCÍPIOS DA RESTAURAÇÃO}

A restauração é a última medida de socorro oferecida a um documento. Ela não é necessária se o acervo possuir condições favoráveis de preservação e conservação; portanto, é importante conservar e preservar para não ter que restaurar. Mas, quando uma obra chega a ponto de ser restaurada, deve-se tomar alguns princípios em consideração, que serão abordados a seguir.

"A restauração constitui o momento metodológico do reconhecimento da obra de arte, na sua consistência física e na sua dúplice polaridade estética e histórica, com vistas à sua transmissão para o futuro." (BRANDI, 2004, p. 30). Essa definição de Brandi diz respeito a obras de arte, mas se aplica também a livros e documentos, pois a restauração destes deve levar em consideração a estética e a historicidade do documento para que sejam transmitidas para o futuro. Por exemplo, o tipo de encadernação, a costura, a douração das letras, o tipo de material utilizado na encadernação, o papel, o estilo de escrita, o tipo de pintura (se existir) e, principalmente, a informação contida no documento, afinal é por isso que ele foi criado. Todas essas características dizem algo sobre a história do livro e devem ser preservadas.

Este mesmo autor afirma que "a restauração deve visar o (sic) restabelecimento da unidade potencial da obra de arte, desde que isso seja possível sem cometer um falso artístico ou um falso histórico" (BRANDI, 2004,

p. 33). Assim, pode-se afirmar que a restauração se preocupa com 0 restabelecimento do objeto sem tirar seus traços artísticos, históricos e de idade. Para que isso aconteça é necessário que antes da restauração se faca uma análise minuciosa das características do objeto para posteriormente restaurá-lo, devolvendo com isso a sua potencialidade sem tirar suas características.

Qualquer comportamento em relação ao documento - nisso compreendendo a intervenção de restauro e a conservação - depende que ocorra primeiramente uma análise geral do documento buscando em suas características históricas, físicas, estéticas e informativas a melhor maneira de realizar um processo de restauração adequado. Dessa forma, pode-se afirmar que não é a restauração que condiciona o documento, e sim o documento que 
condiciona a restauração. Bernard Feilden, em sua entrevista ao Correio da UNESCO, aborda isso quando afirma:

\begin{abstract}
Seja qual for o método de conservação adotado, os seguintes padrões de conduta devem ser rigorosamente observados: 1 ) deve ser feita uma descrição clara e detalhada das condições do objeto, dos métodos e materiais utilizados durante o tratamento; 2) todos os registros históricos devem ser documentados e de modo algum destruídos, falsificados ou removidos; 3) qualquer intervenção deve se limitar ao mínimo necessário e se orientar pelo absoluto respeito à integridade estética, histórica e material dos bens culturais. (...). Além disso, essas intervenções não devem impedir o eventual acesso às diversas indicações de autenticidade contidas no objeto e, por outro lado, devem permitir a conservação da maior parte do material existente. Se forem necessários acréscimos de materiais, esses devem ser menos visíveis que o original, e ao mesmo tempo facilmente identificáveis. (FEILDEN, 1981, p. 27)
\end{abstract}

Levando o pensamento de Feilden para o lado documental podemos dizer que o tipo de papel e sua textura, o tipo de tinta, o estilo de escrita, o estilo de encadernação e os sinais de passagem de tempo são elementos de um documento que possuem considerável importância histórica e devem ser mantidos e conservados. Isso significa que não só a informação contida no documento deve ser preservada, mas o seu suporte, que carrega informações valiosas sobre a história. Sobre restauração, o mesmo autor afirma:

Tem por objetivo revitalizar a concepção original, ou seja, a legibilidade do objeto. A restauração e a restituição de detalhes e características da obra baseiam-se no respeito ao material original, à evidência arqueológica, ao plano inicial e aos documentos autênticos. A reposição de partes que faltam ou que se deterioraram deve se integrar harmoniosamente com o "todo", mas é preciso que, por meio de uma observação atenta, essas partes repostas possam ser distinguidas a fim de que a restauração não falsifique a autenticidade histórica ou artística. (FEILDEN, 1980, p. 27)

A restauração tem o dever de tornar o objeto reutilizável e também de ser sutil e, ao mesmo tempo, identificável, para que não crie um falso histórico e artístico. Tudo deve ser documentado antes e depois do restauro. Não se deve, por exemplo, fazer réplicas de partes deterioradas e sim restabelecê-las, de forma que a intervenção seja visível.

Viollet-le-Duc (2000, p. 29) ousa quando diz que "restaurar um edifício não é mantê-lo, repará-lo ou refazê-lo, é restabelecê-lo em um estado completo que pode não ter existido nunca em um dado momento." Levando a sua definição para o lado dos livros e documentos, pode-se dizer que restaurar não é simplesmente manter ou reparar (pois isso é preocupação da conservação) 
nem refazer (que se refere à uma cópia fidedigna ao documento), mas sim restabelecer, para que o objeto possa ser reutilizável.

Outro ponto de extrema importância na restauração é a reversibilidade de suas intervenções, pois elas não devem prejudicar uma futura intervenção que porventura se torne necessária. Os materiais acrescentados no processo de restauração devem visar ao restabelecimento da obra e não podem ser partes irremovíveis da mesma.

Levando em consideração os princípios da restauração, conclui-se que ela restabelece um objeto devolvendo sua potencialidade, mas sem anular seus traços artísticos, históricos e informativos ou os falsificar. Ela deve ser reversível, facilmente identificável e minuciosamente documentada. 


\section{ESTUDO DE CASO}

\subsection{A Universidade de Brasília (UnB)}

A Universidade de Brasília (UnB) é uma das mais importantes Instituições de Ensino Superior do Brasil. Fundada em 21 de abril de 1962, seu campus principal está localizado na área central da capital do país e ocupa 395 hectares. A UnB é uma instituição pública, pluridisciplinar de formação dos quadros de profissionais de nível superior, de pesquisa e de extensão. Provê educação tanto terciária (graduação) quanto quaternária (pós-graduação).

São finalidades essenciais da Universidade de Brasília o ensino, a pesquisa e a extensão, integrados na formação de cidadãos qualificados para o exercício profissional e empenhados na busca de soluções democráticas para os problemas nacionais. (ESTATUTO, art. $3^{\circ}$ ).

Atualmente a UnB oferece 72 cursos de graduação, 64 de mestrado, 45 de doutorado e dezenas de especializações. Os cursos de graduação e pósgraduação oferecidos por ela estão divididos em: estudos de ciência básica, com 12 institutos voltados para formar pesquisadores e especialistas de alto nível; e estudos de ciência aplicada, com 13 faculdades direcionadas à educação profissional e técnica

10.1.1. O Departamento de Ciência da Informação e Documentação (CID)

A Faculdade de Economia, Administração, Contabilidade e Ciência da Informação e Documentação (FACE) é uma das treze faculdades que pertencem à UnB e são direcionadas à educação profissional e técnica. A FACE é composta por quatro departamentos, dentre eles o Departamento de Ciência da Informação e Documentação (CID), que oferece cursos de graduação, pós-graduação, extensão e especialização na área de informação e documentação. A Ciência da Informação $(\mathrm{Cl})$ é assim conceituada por SARACEVIC (1996): 
[...] um campo dedicado às questões científicas e à prática profissional voltadas para os problemas da efetiva comunicação do conhecimento e de seus registros entre os seres humanos, no contexto social, institucional ou individual do uso e das necessidades de informação. No tratamento destas questões são consideradas de particular interesse as vantagens das modernas tecnologias informacionais. (SARACEVIC, 1996, p. 47).

Diante deste conceito de $\mathrm{Cl}$, conclui-se que o Departamento de Ciência da Informação e Documentação da UnB se preocupa em oferecer cursos e em educar profissionais que se dediquem ao conhecimento registrado (em suas mais variadas formas), tanto em seus problemas quanto em sua disseminação.

Os cursos de graduação oferecidos pelo CID são:

- Arquivologia (Bacharel): funciona desde 1991 e forma profissionais responsáveis pelo gerenciamento da informação, gestão documental, conservação, preservação e disseminação da informação contida nos documentos (especialmente arquivísticos);

- Biblioteconomia (Bacharel): funciona desde 1962 e forma profissionais aptos a trabalhar com a informação, independente do espaço no qual ela se insere, porém focado na biblioteca. Cabe ao bibliotecário exercer as seguintes atividades: nível gerencial: planejamento, administração, supervisão e assessoramento; nível operacional: seleção, aquisição, análise e síntese, armazenamento, recuperação e disseminação dos registros do conhecimento humano em todos os tipos de suporte (revistas, jornais, vídeos, livros, patentes, mapas, discos, partituras musicais, relatórios e, de forma crescente, documentos eletrônicos); nível educacional: ensino, extensão e pesquisa;

- Museologia (Bacharel): abriu sua primeira turma no segundo semestre de 2009 e formará bacharéis com condições de interpretar as relações entre Homem, Natureza e Cultura, contextualizando-as temporal e espacialmente e também de compreender o museu em suas relações com sistemas de pensamento e códigos sociais variados.

Atualmente o CID oferece 38 disciplinas, dentre elas, Conservação e Restauração de Documentos, que estuda instalações e equipamentos adequados à conservação e restauração de documentos dos depósitos de 
arquivos ou bibliotecas. A disciplina aborda também, e entre outros assuntos, os agentes de deterioração dos suportes de documentos e como combatê-los. Porém, essa matéria ainda não possui um módulo prático por falta de um laboratório de conservação e restauração que receba os alunos, e isso faz com que o curso fique limitado. Sendo essa uma disciplina de extrema relevância para a formação de um profissional da informação, é muito importante que aconteça uma mudança nesse quadro.

\subsubsection{O Centro de Documentação da UnB (CEDOC)}

O Centro de Documentação da UnB, criado provisoriamente como CEDAQ (Centro de Documentação e Arquivo da Universidade de Brasília), em agosto de 1986, pelo Ato da Reitoria № 345/86 e constituído como Centro de Custo pelo Ato da Reitoria № 596/88, de 24 de outubro de 1988 com o nome de Centro de Documentação - CEDOC, é órgão de assessoramento da Administração Superior da Universidade de Brasília. Tem por finalidade recolher, preservar e garantir o acesso aos documentos arquivísticos de valor permanente produzidos e acumulados pelas áreas meio e fim da Fundação Universidade de Brasília (FUB), bem como aos bens culturais históricos, constituindo-se em instrumento de apoio à administração, à cultura, à história e ao desenvolvimento científico e tecnológico, de acordo com os interesses da Universidade.

O acervo do CEDOC é composto de documentos textuais, micrográficos, cartográficos e audiovisuais. Portando, existe uma coleção de diferentes tipos de suporte sob a sua guarda (papel, película e fita magnética). A manutenção deste acervo é feita através de uma Comissão Avaliadora de Documentos, que é uma parceria entre o CEDOC e o CID, na qual os arquivistas e estagiários do Departamento e funcionários do Centro se envolvem com a classificação e o tratamento dos documentos. 
10.1.2.1. O Laboratório de Restauração do CEDOC

O CEDOC possui um laboratório de conservação e restauração de documentos gráficos onde são realizadas atividades de conservação e restauro dos documentos do próprio arquivo do Centro, do Setor de Obras Raras da Biblioteca Central da UnB e de instituições que fecham contratos temporários com o laboratório.

O laboratório conta com mão-de-obra especializada (em sua maioria contratada) para cumprir seu papel de conservar e restaurar documentos, o que exige muita competência e habilidade. É relativamente bem equipado, pois possui bons aparelhos como máquina obturadora de papel (MOP), mesa de sucção, balança de precisão, deionizador de água, entre outros. Porém, necessita de mais espaço físico para realizar suas atividades. 


\section{SOBRE O LIVRO}

O livro escolhido para este estudo de caso pertence ao acervo de Obras Raras da Universidade de Brasília. Seu titulo é "Methodo para determinar as horas das Occultações de estrelas pela lua", escrito por Louis Ferdinand Cruls (1848-1908), belga, naturalizado brasileiro, que foi diretor do Imperial Observatório do Rio de Janeiro e, com a República, do Observatório Nacional, de 1881 a 1908. Este cientista e astrônomo deu grande contribuição à ciência. Um de seus grandes trabalhos ocorreu em 1892-93, quando chefiou a Comissão Exploradora do Planalto Central, demarcando o atual Distrito Federal para a instalação da Nova Capital (Brasília). Em 1886, criou o primeiro periódico de Ciências do Brasil, a Revista do Observatório. Trata-se de um livro de 1899 editado no Rio de Janeiro.

\subsection{Análise Inicial}

A análise inicial tem o objetivo de identificar as características físicas e históricas do livro. Para isso o CEDOC possui uma ficha que deve ser preenchida antes de iniciar a restauração (ANEXO A).

Foi observado que o livro possui $23 \mathrm{~cm}$ de largura, $32,3 \mathrm{~cm}$ de altura e $1,5 \mathrm{~cm}$ de espessura. Sua encadernação é inteira, sem lombada e com letras douradas. No miolo ${ }^{1}$, o tipo de papel utilizado é feito com fibras de madeira (pois se trata de um livro editado no final do século XIX), presente também na folha de guarda; não foi possível identificar o estilo de costura por estar danificada e partida.

\footnotetext{
${ }^{1}$ Conjunto de folhas ordenadas e costuradas em um bloco que será encadernado.
} 


\subsection{Tipos de Ocorrência}

\subsubsection{Capa}

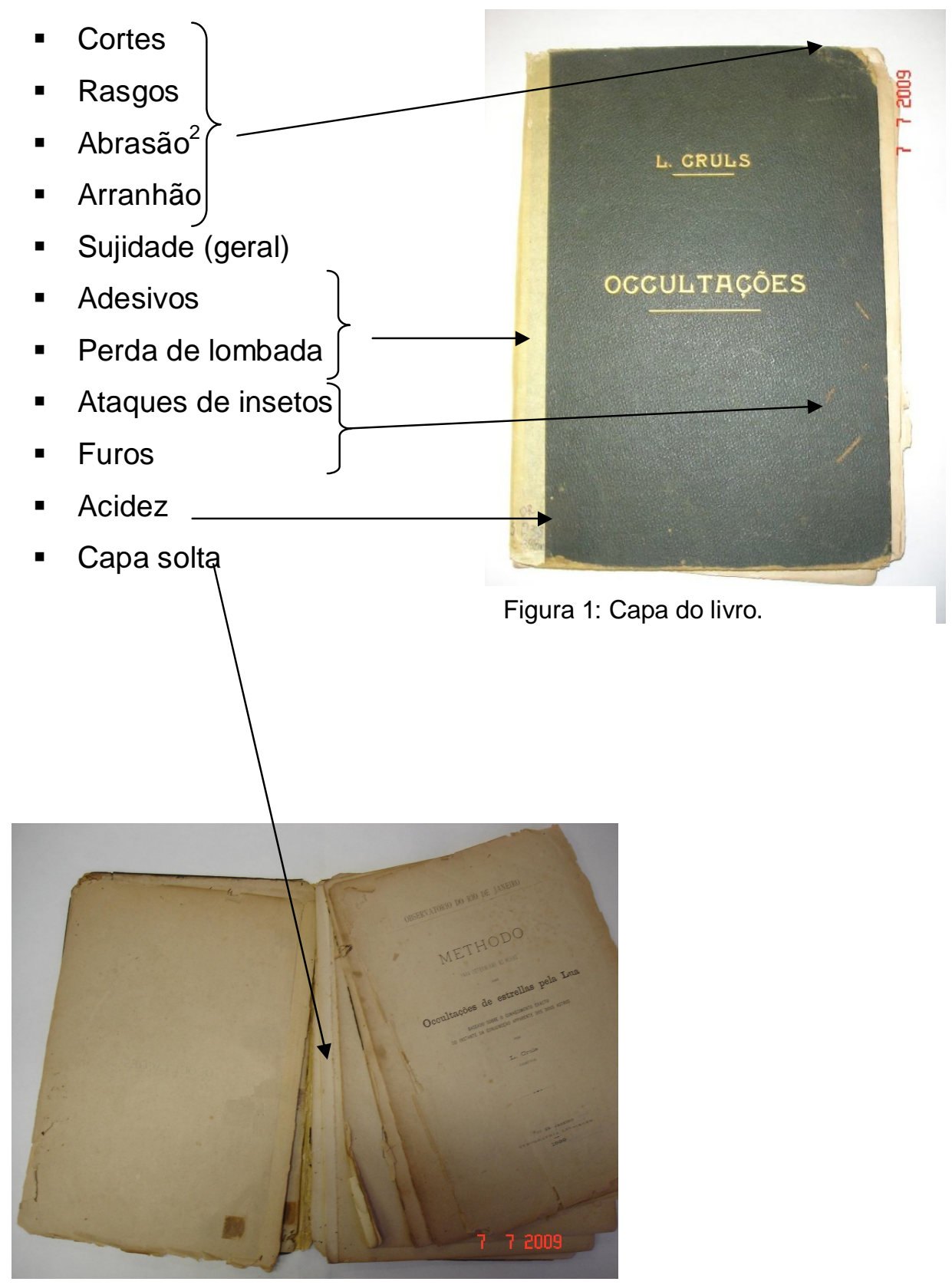

Figura 2: Lombada solta.

\footnotetext{
${ }^{2}$ Danos causados por excesso de peso sobre o documento.
} 
11.2.2. Miolo

- Sujidade (geral)

- Abrasão

- Bordas fragilizadas

- Rasgos

- Cortes

- Dobras

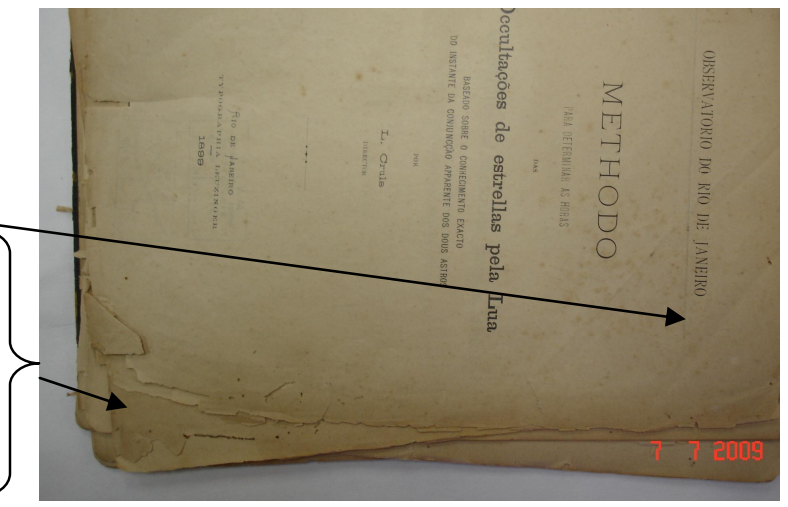

Figura 3: Miolo.

- Ataques de insetos (broca)

- Furos

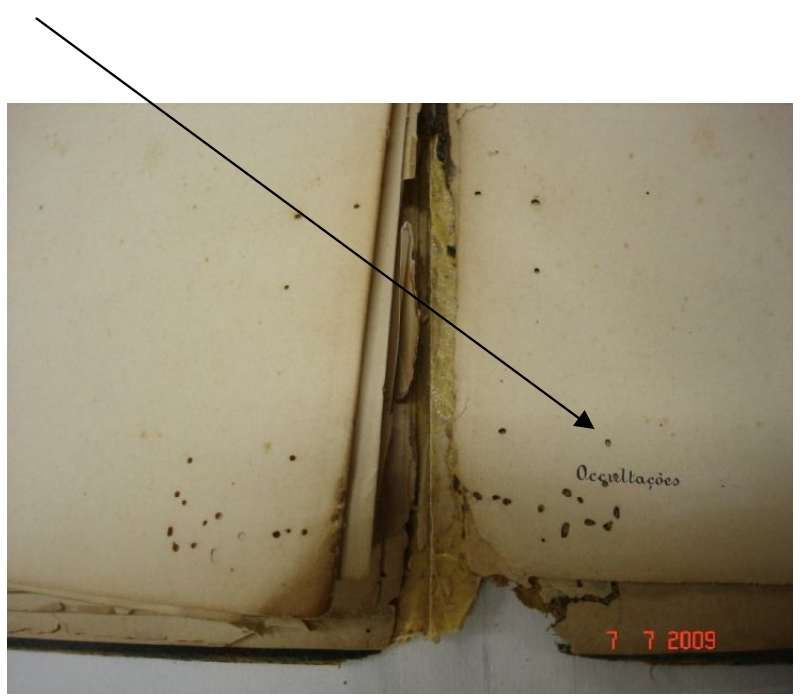

Figura 4: Ataques de brocas. 


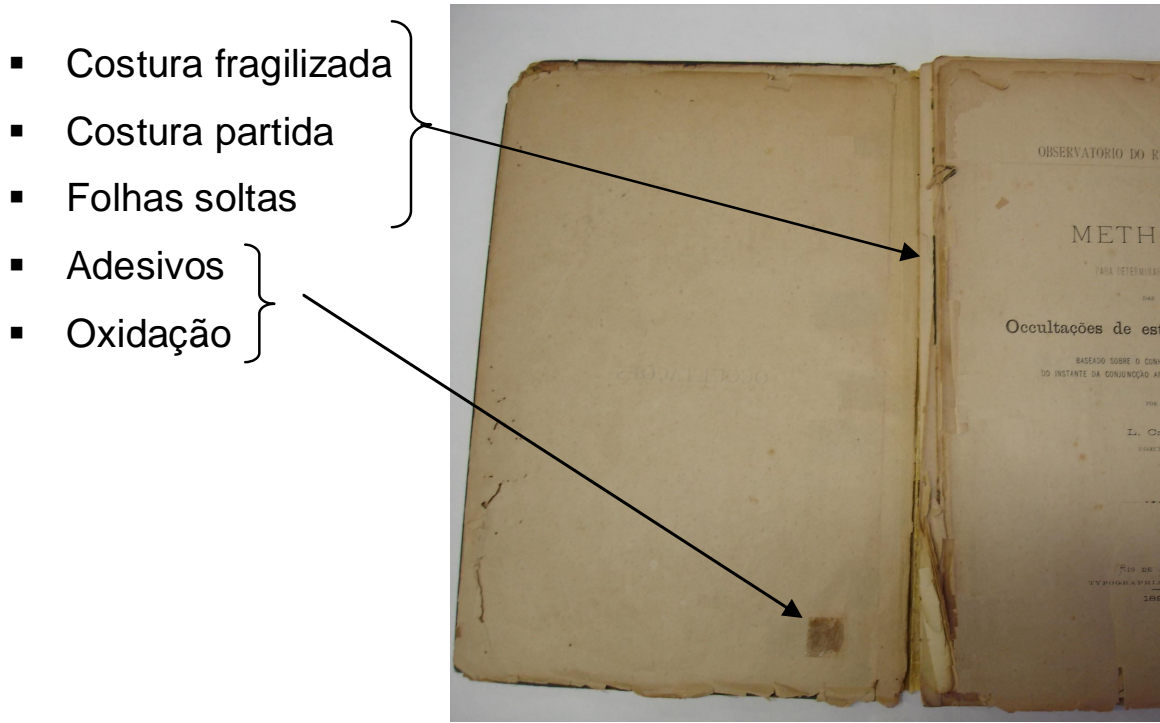

Figura 5: Costura e adesivo.

- Pontos de oxidação
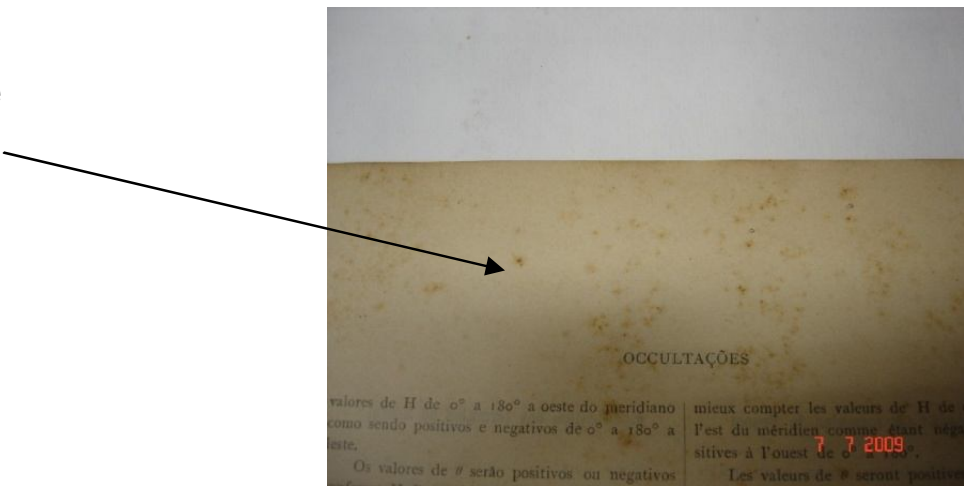

Figura 6: Oxidação.

- Carimbos

- Anotações em grafite

- Anotações em tinta

Figura 7: Carimbo. 


\section{TÉCNICAS DE RESTAURO REALIZADAS NO MIOLO}

\subsection{Numeração e desmonte do livro}

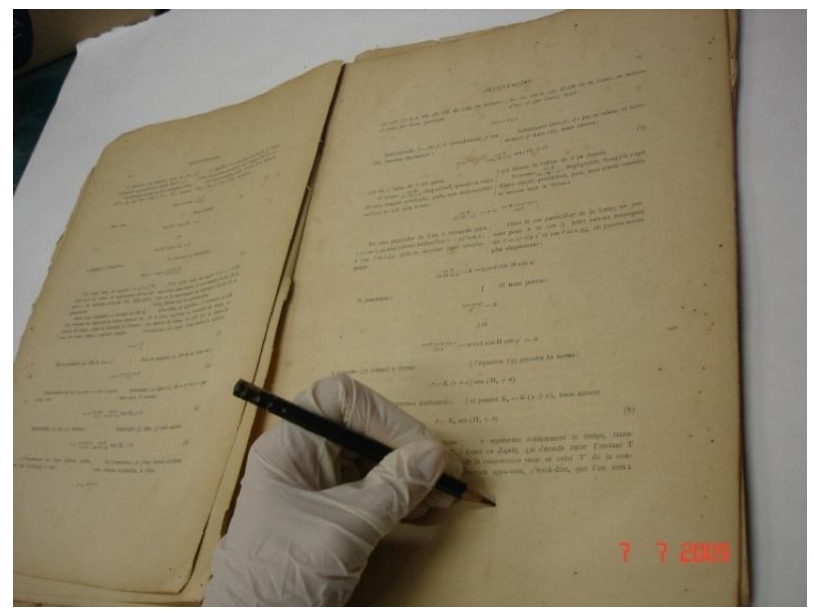

Figura 8: Numeração do livro.

O livro encontrava-se praticamente desmontado, pois sua costura estava toda partida. A numeração do livro é feita a lápis (lápis macio, número 6B) e se torna necessária a partir do momento em que o livro é desmontado, para manter a ordem original das folhas, pois nem sempre se pode confiar na numeração de páginas do livro. Para algumas técnicas de restauração, como a desacidificação aquosa (será abordada mais adiante) e a costura nova, é imprescindível que o desmonte do livro seja feito e, consequentemente, sua numeração.

\subsection{Higienização}

A higienização tem o objetivo de eliminar todas as sujidades presentes no livro, pois a poeira, combinada com condições inadequadas de temperatura e umidade relativa, escurece a tonalidade do papel e ocasiona manchas muitas vezes irreversíveis, como pontos de ferrugem ou de oxidação (também chamados de foxing, por lembrarem a cor de um tipo de raposa, fox, em inglês). Jaime Spinelli afirma que o termo higienização tem dois sentidos: 
O primeiro é médico: parte da medicina que propaga os meios para conservar a saúde e prevenir enfermidades, indicando ao homem quais são suas necessidades orgânicas e de que maneira deve satisfazê-las para conservarse saudável. O outro é pedagógico: numa dupla perspectiva, a que ensina a higiene corporal de uma pessoa e a que refere à higiene escolar propriamente dita. (SPINELLI, 1997, p. 39)

A higienização conserva a saúde do documento prevenindo enfermidades (manchas, fungos, oxidação, ataques de insetos, etc.) e é uma questão de higiene propriamente dita. O momento da higienização é também um momento de contato que o conservador tem com o documento para identificar danos que o mesmo venha sofrendo e procurar resolvê-los.

A seguir serão ilustradas e explicadas as técnicas de higienização aplicadas no estudo de caso, que são: higienização com trincha folha por folha; retirada de sujidades e pontos de ferrugem com bisturi; e limpeza com aplicação de pó de borracha.

12.2.1. Higienização com trincha folha por folha

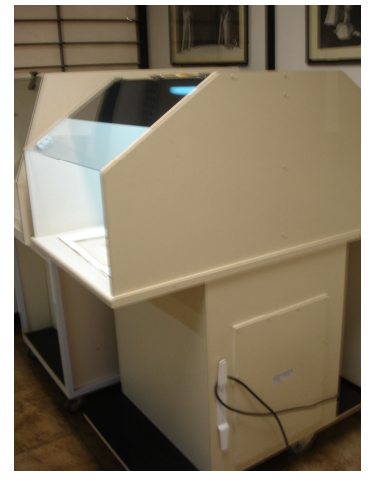

Figura 9: Máquina de sucção.

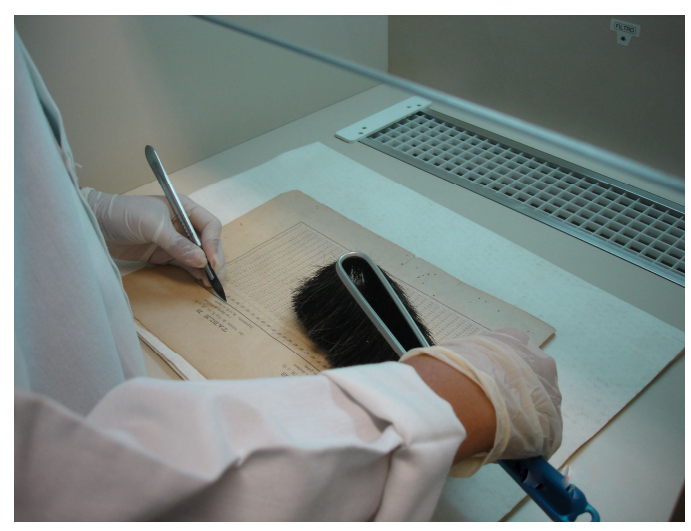

Figura 10: Higienização com trincha.

Para se fazer uma boa higienização é necessário uma trincha, para auxiliar na retirada de sujidades que se depositam entre as folhas do livro, e 
uma câmara de sucção, para a deposição desses resíduos. Dentro da câmara de sucção a trincha foi passada em todas as folhas do livro.

12.2.2. Retirada da sujidades e pontos de ferrugem com bisturi

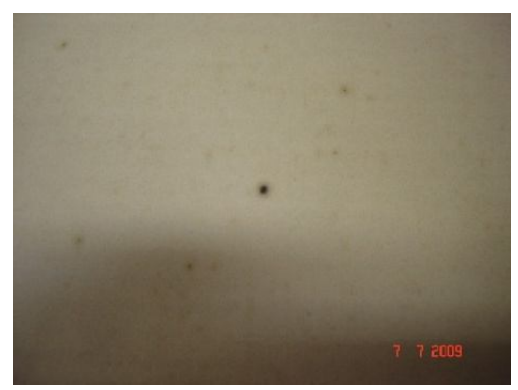

Figura 11: Resíduo de ferrugem.

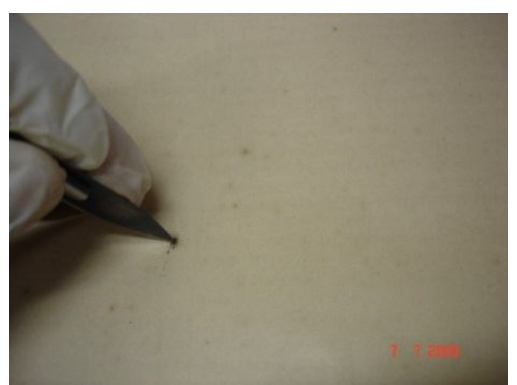

Figura 12: Retirada do resíduo de ferrugem com bisturi.

Sujeiras acumuladas entre as folhas do livro ou elementos intrínsecos do suporte podem, com o tempo e a alta umidade relativa do ar, penetrar nas fibras do papel e ocasionar pontos pretos (manchas) e resíduos de ferrugem. Esses resíduos são prejudiciais ao documento, pois migram de uma folha para outra e, se atingirem uma região escrita, acarretarão perda irreversível de informação. Esses pontos de ferrugem estavam presentes em todas as folhas do livro e foram retirados com o bisturi, dentro da câmara de sucção. Entretanto, quando se retiram esses pontos, em alguns casos, um buraco fica no local; esses buracos serão preenchidos posteriormente.

12.2.3. Limpeza com aplicação de pó de borracha

A limpeza com aplicação de pó de borracha (borracha plástica ralada) foi necessária em folhas que apresentavam grande acúmulo de sujidade e pontos de ferrugem que não saíram com a trincha. Esse pó deve ser aplicado com 
movimentos circulares em áreas sem escrita, pois, se essa área for atingida, pode ocorrer desgaste da tinta e, consequentemente, perda de informação.

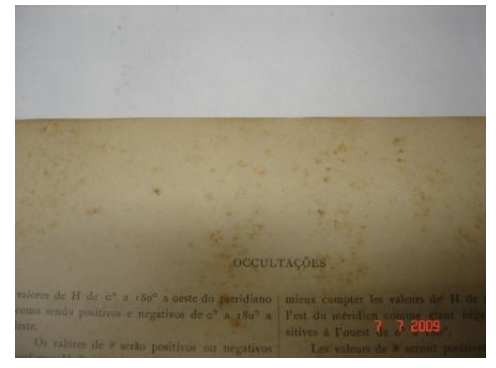

Figura 13: Antes da aplicação do pó de borracha.

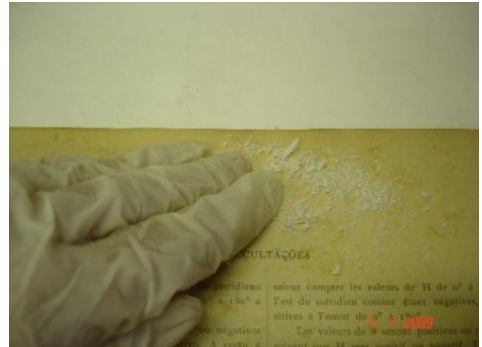

Figura 14: Durante a aplicação do pó de borracha.

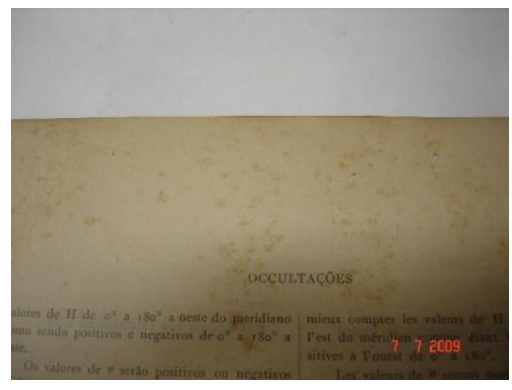

Figura 15: Após a aplicação do pó de borracha. 


\subsection{Desacidificação aquosa (banho)}

A desacidificação aquosa é aplicada em documentos que se encontram visivelmente ácidos, ou seja, documentos cuja tonalidade do papel está escura. A desacidificação branqueia o documento, fornece reserva alcalina, remove impurezas e aumenta a maleabilidade.

"A desacidificação aquosa é uma etapa imprescindível anterior ao tratamento na MOP." (PEREIRA, 2007, p. 262). O tratamento na MOP consiste em reintegrar partes faltantes ao suporte e será detalhado mais adiante.

O livro estudado neste trabalho apresenta tonalidade escura em suas folhas e necessidade de reintegração de partes faltantes. Então, tornou-se necessária a realização da desacidifição aquosa.

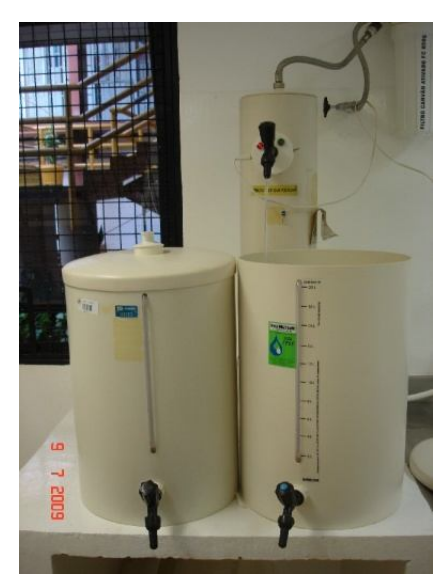

Figura 16: Deionizador de água.

O banho no livro é feito com água deionizada, que é uma água livre de íons e com a carga elétrica neutralizada para impedir reações químicas com o papel. O laboratório do CEDOC possui um deionizador de água, como mostra a Figura 16. O primeiro passo para começar o banho foi fazer o teste de solubilidade das tintas presentes no documento, colocando uma gota de água sobre uma pequena área de tinta. Observando que a tinta não era solúvel na água, iniciou-se o processo do banho. 
O segundo passo foi providenciar três cubas grandes (que tenham a dimensão maior que a das folhas do livro) e em cada cuba preparar um tipo de solução, como será explicado a seguir:

\section{Cuba 1}

A primeira cuba é composta de água deionizada quente (no máximo $40^{\circ} \mathrm{C}$ ).

\section{Cuba 2}

$\mathrm{Na}$ segunda, deve-se apenas encher com água deionizada fria, (aproximadamente $23^{\circ} \mathrm{C}$ ).

\section{Cuba 3}

Na ultima cuba é feita uma mistura de água deionizada e solução alcalina, para fornecer reserva alcalina às folhas. Essa solução é composta de Hidróxido de Cálcio $(2,5 \mathrm{~g} / 2 \mathrm{l})$ e Carbonato de Cálcio (4,5g/2l). Deve-se acrescentar a solução alcalina aos poucos e medir o PH da água até que esteja entre 8 e 9.

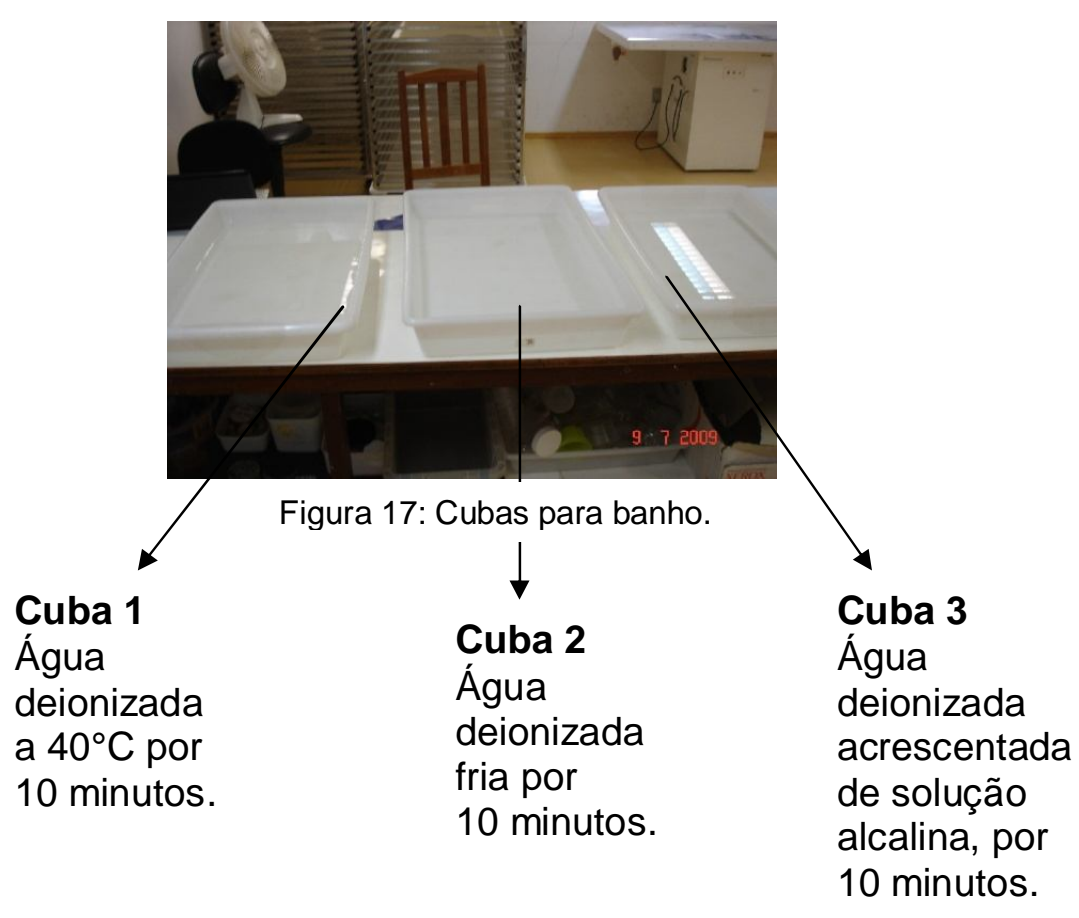


O próximo passo foi colocar as folhas do livro entre crepes (telas de nylon), fazendo um sanduíche de, no máximo, quatro camadas para não dificultar a penetração da água nas folhas, como na Figura 18.

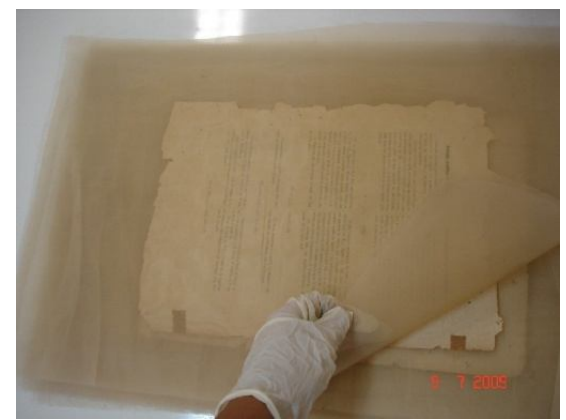

Figura 18: Folhas entre crepes.

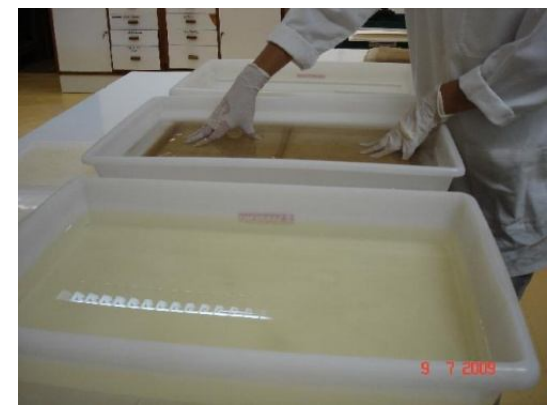

Figura 19: Cuba 1 após a imersão das folhas.

Em seguida, deve-se mergulhar o sanduíche de crepes e folhas primeiramente na Cuba 1, em seguida na Cuba 2 e 3, respectivamente. As folhas ficam submersas em cada cuba durante 10 minutos. Note na Figura 19 como a água da Cuba 1 ficou escura após a imersão das folhas.

Após tirar as folhas da Cuba 3, deve-se colocá-las pra secar na secadora, como mostra a Figura 21.

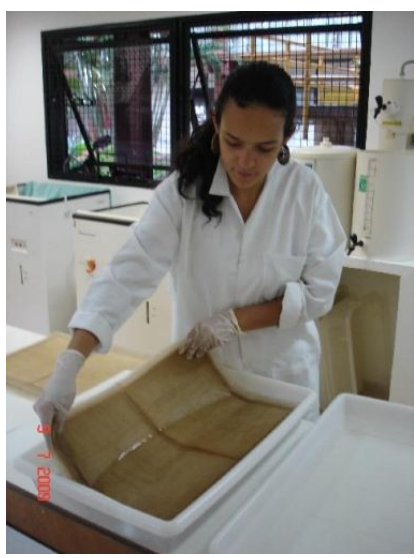

Figura 20: Tirando as folhas da Cuba 3.

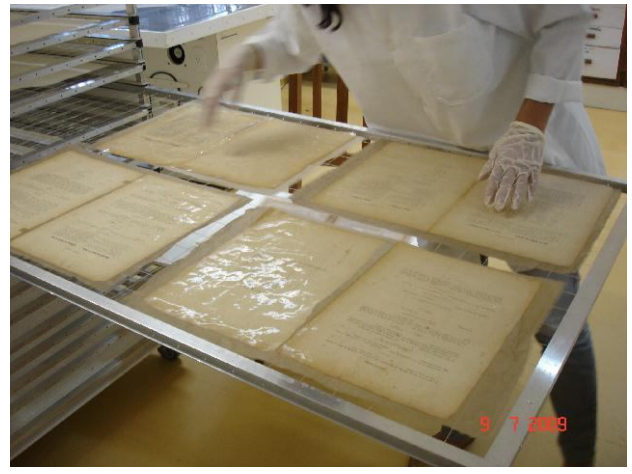

Figura 21: Secadora. 
O banho foi dado em todas as folhas do livro e se observou que, ao final, elas apresentavam uma tonalidade mais clara e houve um aumento em sua maleabilidade, resultado esse alcançado graças à estabilização da acidez do papel e à remoção de impurezas.

\subsection{Remoção de marca ocasionada por fita adesiva}

As fitas adesivas de fabricação moderna são de filmes de acetato, adesivos a base de borracha e de resinas acrílicas. Essas colas sintéticas ocasionam manchas e diminuem a resistência da região afetada. Antigamente, as colas das fitas adesivas eram de origem vegetal, que, geralmente, são de fácil remoção. Ingrid Beck explica a diferença entre a cola vegetal e a sintética quando afirma:

Enquanto na remoção das manchas provocadas por colas vegetais basta a aplicação de água morna no local, absorvendo o resíduo de colas, as fitas adesivas modernas, quando recém aplicadas, devem ser retiradas com cuidado a fim de não lesar a superfície do documento. Quando o adesivo de resina penetrou no papel e já se estabeleceu a mancha amarelada, a remoção exige um trabalho especializado. (BECK, 1985, p. 17).

O livro apresentava mancha amarelada ocasionada pela penetração da resina do adesivo; isso exigiu um trabalho especializado.

O primeiro passo para o início do processo de remoção deste tipo de marca é providenciar: talco neutro ou amido de milho; papel mata-borrão; algodão; palito de churrasco; tela de nylon e Acetato de etila.

O solvente utilizado para tirar a mancha ocasionada pela fita adesiva foi o Acetato de etila, que é da família dos ésteres e classificado como um solvente médio, sendo o mais indicado para dissolver vernizes resinosos.

Primeiramente, em cima do papel mata-borrão foi colocada uma camada de talco neutro com a mesma dimensão da área manchada, sendo que a camada ficará por baixo da mancha, como na Figura 22. 


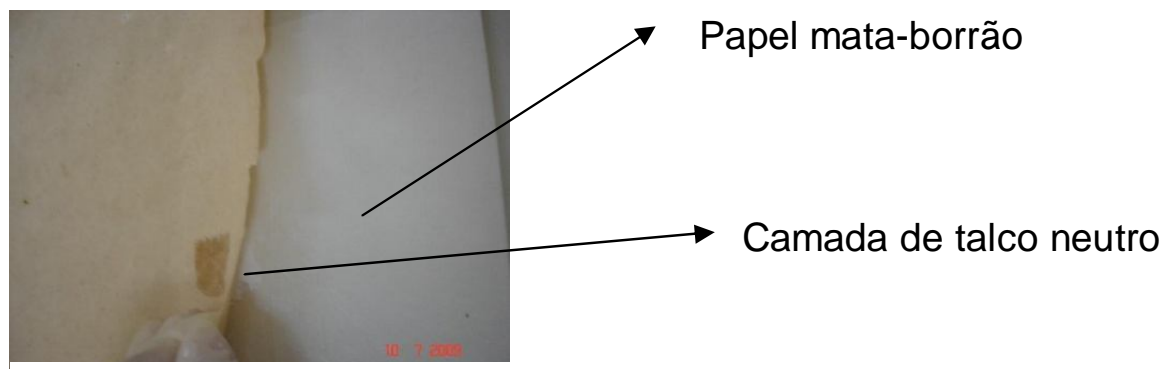

Figura 22: Preparo para a remoção.

Depois foi colocada mais uma camada de talco neutro por cima da mancha, também com a mesma dimensão da área manchada, como ilustra a Figura 23. Então, por cima do mata-borrão foi feito um sanduíche de camadas de talco neutro, cujo recheio é a área manchada.

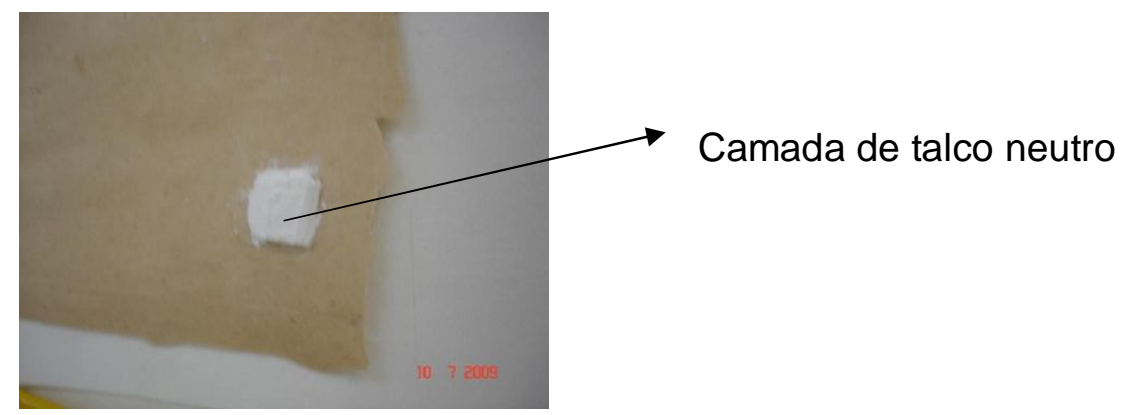

Figura 23: Camada de talco neutro.

A próxima etapa foi colocar um crepe sobre o sanduíche e preparar o palito de churrasco colocando um chumaço de algodão em sua ponta. Posteriormente, essa ponta foi embebida no Acetato de etila e passada cuidadosamente sobre o crepe na parte que possui talco neutro, como ilustra a Figura 24. Em seguida, colocou-se uma folha de papel mata-borrão sobre o processo feito e se pressionou com os dedos durante cinco segundos, para que o Acetato de etila atingisse a parte manchada, como na Figura 25. 


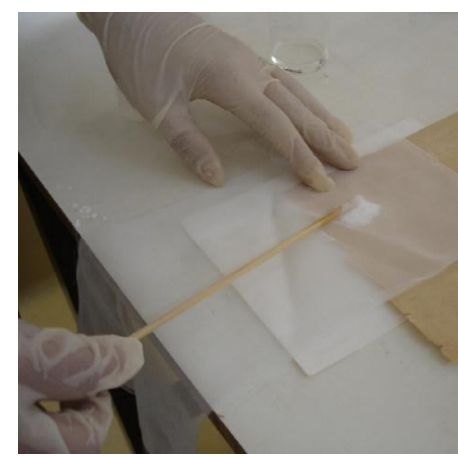

Figura 24: Aplicação de Acetato de etila.

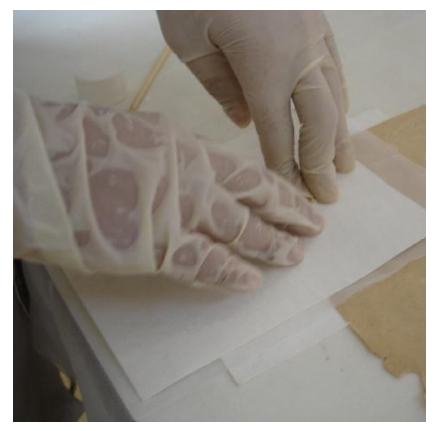

Figura 25: Pressão sobre a aplicação.

Esse processo foi repetido quatro vezes, que é o máximo recomendado, pois o Acetato de etila é um solvente forte, que, se usado em excesso, pode enfraquecer o papel. A cada nova aplicação deve-se trocar o talco.

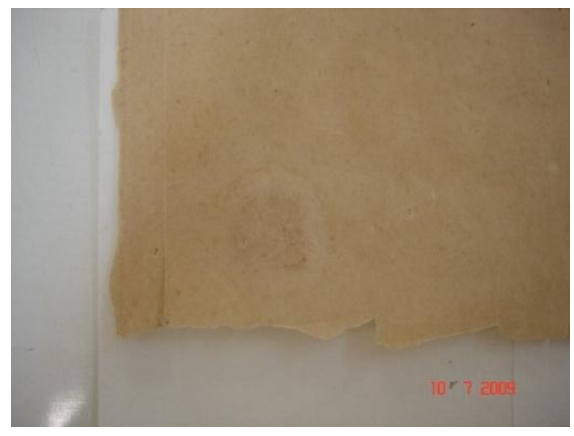

Figura 26: Resultado após quatro aplicações.

A mancha ocasionada pela cola da fita adesiva ficou muito mais clara, mas infelizmente não foi totalmente removida.

\subsection{Reintegração Mecânica com Reforço}

A reintegração mecânica com reforço consiste em devolver ao documento com áreas faltantes a mesma quantidade de massa perdida, 
através do processo de formação de papel na MOP; e o reforço simultâneo é uma folha de baixíssima gramatura adicionada ao suporte para ajudar na aderência do novo papel para devolver ao suporte resistência e condições de manuseio. A seguir serão explicadas as fases desse processo:

12.5.1. Cálculo da massa faltante

O primeiro procedimento foi cotar a quantidade de massa necessária para reintegrar o documento, por operação na MOP, de acordo com a área útil da máquina. Assim, foram escolhidas aleatoriamente quatro folhas perfeitas para serem pesadas na balança de precisão e calcular a média da massa de uma folha perfeita, como mostrado a seguir:

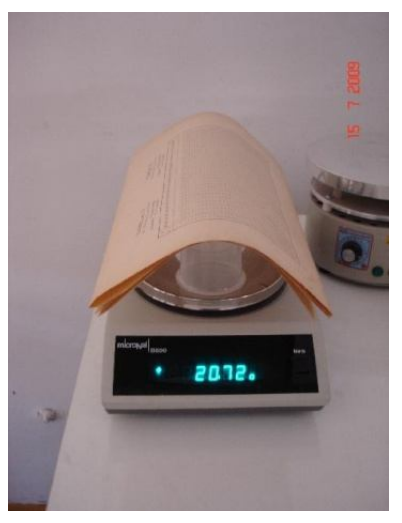

1) $O$ peso de quatro folhas saudáveis é $20,72 \mathrm{~g}$; então, uma folha pesa $5,18 \mathrm{~g}$.

2) A folha mede $32,2 \times 22,8 \mathrm{~cm}$, portanto sua área é de $734,16 \mathrm{~cm}^{2}$.

3) Dividindo o peso pela área, temos a gramatura (G) de $0,00705 \mathrm{~g} / \mathrm{cm}^{2}$.

\section{Então $\mathbf{G}=\mathbf{0 , 0 0 7 0 5} \mathbf{~ g / c m 2}$}

Figura 27: Peso das folhas saudáveis.

Depois da gramatura do documento ser calculada, multiplicou-se esta pela área útil da MOP:

$$
\begin{aligned}
& \text { Área da MOP }=3100,62 \mathrm{~cm}^{2} \\
& \mathrm{G} \times 3100,62=\mathrm{m} \\
& \mathbf{m}=\mathbf{2 1 , 8 7 6} \mathbf{g}
\end{aligned}
$$


Então, $\mathbf{m}$ é a massa de fibra necessária para se fazer uma folha na MOP com a mesma gramatura das folhas do livro. Assim, subtraindo de $\mathbf{m}$ a massa total $\mathrm{da}(\mathrm{s})$ folha(s) a ser(em) processada(s), teremos a massa de fibras necessária para cada operação na máquina, como foi feito a seguir:

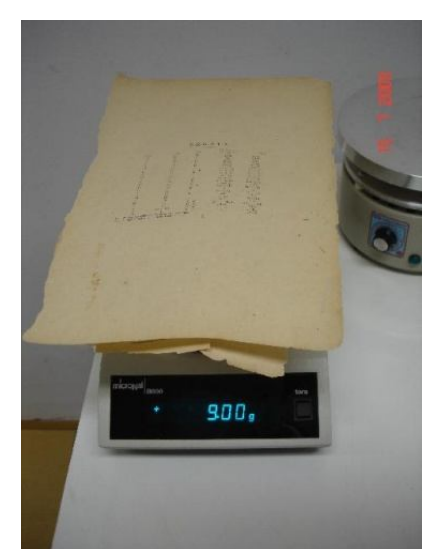

1) As duas folhas que serão processadas na MOP, juntas, pesam $9 \mathrm{~g}$.

2) $\mathbf{m}-9=12,876 \mathrm{~g}$

Figura 28: Peso das folhas a serem processadas.

Assim, 12,876 g é a quantidade de massa que deverá ser acrescentada no processamento de reintegração destas folhas na MOP.

12.5.2. Preparo da suspensão de fibras

O laboratório do CEDOC possui um catálogo de papéis em vários tons feitos com a mixagem de diferentes cores do papel ingres (papel livre de acidez e resistente à luz). Esses papéis feitos no laboratório são usados para fazer reintegração mecânica e enxertos em folhas e documentos a serem restaurados. Foi escolhido, então, um papel com o tom mais próximo ao da folha do livro; em seguida, este foi picotado para ser batido no liquidificador com água, formando assim a suspensão, uma espécie de sopa de polpa de papel.

Para preparar a suspensão de fibras foi adotado um volume de suspensão padrão que é de $1 \%$, ou seja, para cada $100 \mathrm{ml}$ de água se coloca 1 $g$ de fibra. 


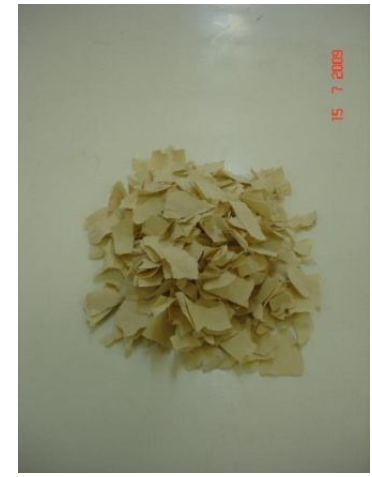

Figura 29: Papel picotado.

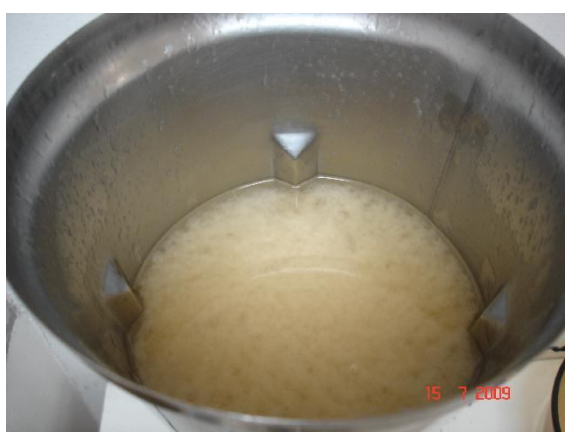

Figura 30: Suspensão.

Agora se pode calcular a quantidade de litros de suspensão necessária para fazer a reintegração das folhas:

12.5.3. Parte prática

Primeiro as folhas foram dispostas sobre a tela de nylon na MOP.

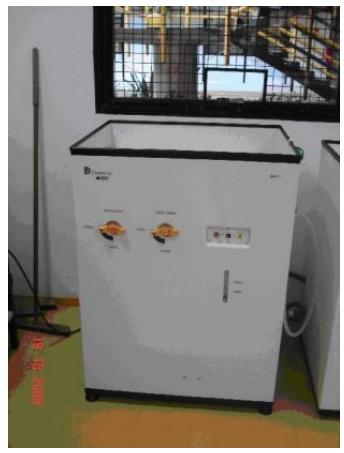

Figura 31: Maquina Obturadora de Papel.

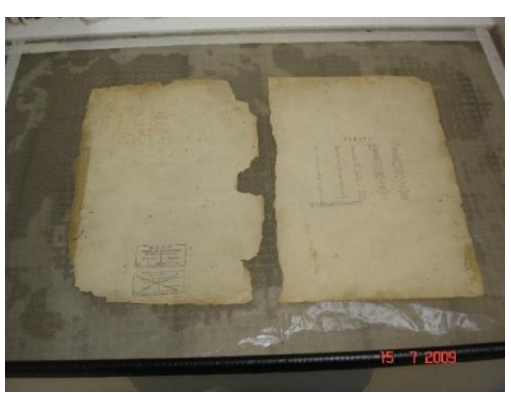

Figura 32: Folhas dispostas na MOP. 
Depois se formou um espelho d'água sobre esse conjunto fixado com a grade e se acrescentou a suspensão de fibra. A suspensão foi misturada para se tornar homogênea.

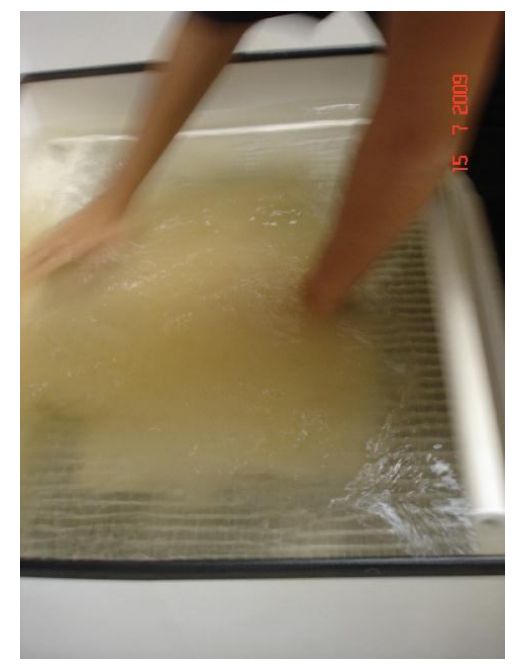

Figura 33: Suspensão misturada.

Posteriormente, a grade foi removida rapidamente para não deixar marcas no papel e se procedeu ao deságue, para obter o preenchimento das áreas faltantes.

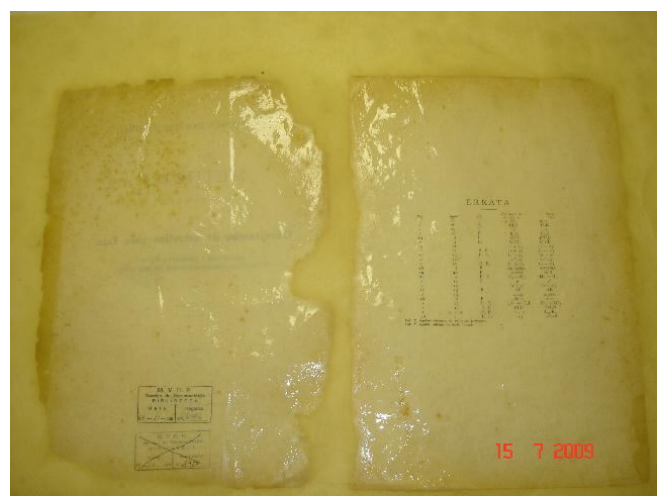

Figura 34: Documento após o deságue. 
Após o deságue, o material foi retirado com cuidado e levado à secagem. O documento foi colocado sobre um papel mata-borrão e protegido com outra tela de nylon e outro papel mata-borrão; em seguida, todo o conjunto foi colocado entre tábuas. Finalmente, pesos foram colocados por cima das tábuas por alguns minutos. Não é recomendado usar prensa no documento molhado, pois se trata de um peso muito forte, que pode modificar a textura do papel.

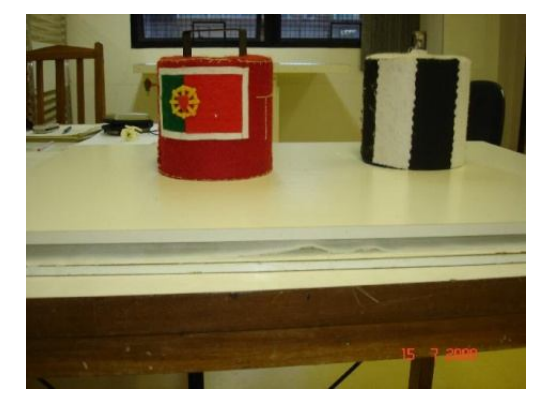

Figura 35: Documento sob pesos.

Enquanto o material está passando por uma leve secagem, foi feita uma folha de reforço sobre a tela de nylon na MOP, de $6 \mathrm{~g} / \mathrm{m}^{2}$, da seguinte forma:

1) Se a área da MOP é de $0,31 \mathrm{~m}^{2}$ e deveria ser feita uma folha de $6 \mathrm{~g} / \mathrm{m}^{2}$, a quantidade de fibra necessária, em gramas, era $1,86 \mathrm{~g}$.

2) Se cada $100 \mathrm{ml}$ possui $1 \mathrm{~g}$ de fibra, então, para adquirir 1,86 g serão necessários 186 ml de suspensão.

Assim, a folha de reforço foi formada na MOP e os pesos foram retirados do documento. Em seguida foi passada cola metilcelulose $\mathrm{e}^{3}$ em toda a extensão da folha, em movimentos de fora para dentro (para não danificar as margens

\footnotetext{
${ }^{3}$ Cola vegetal, livre de acidez e de aplicação reversível.
} 
recém formadas). A folha de reforço foi retirada da MOP e colocada sobre o documento.

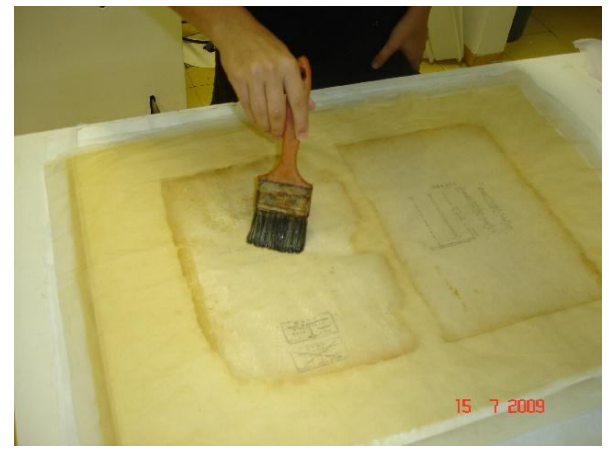

Figura 36: Camada de metilcelulose.

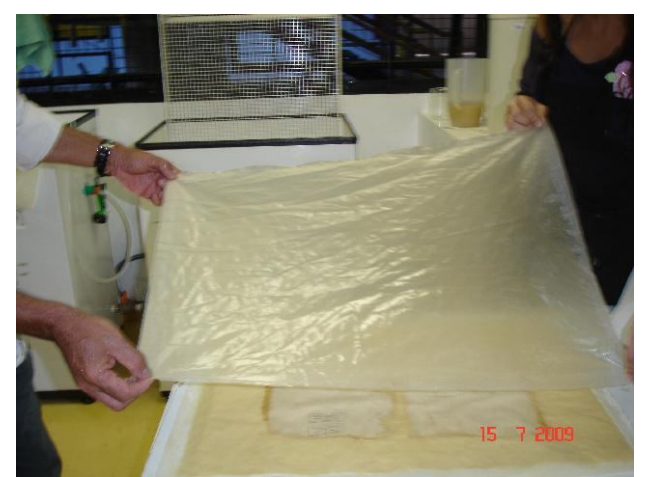

Figura 37: Inserção da folha de reforço.

A folha foi levada para secagem sob os pesos novamente; porém, desta vez, assim permaneceu até sua secagem definitiva, trocando-se os papéis mata-borrão sempre que necessário.

Após a secagem a folha adquiriu o seguinte aspecto:

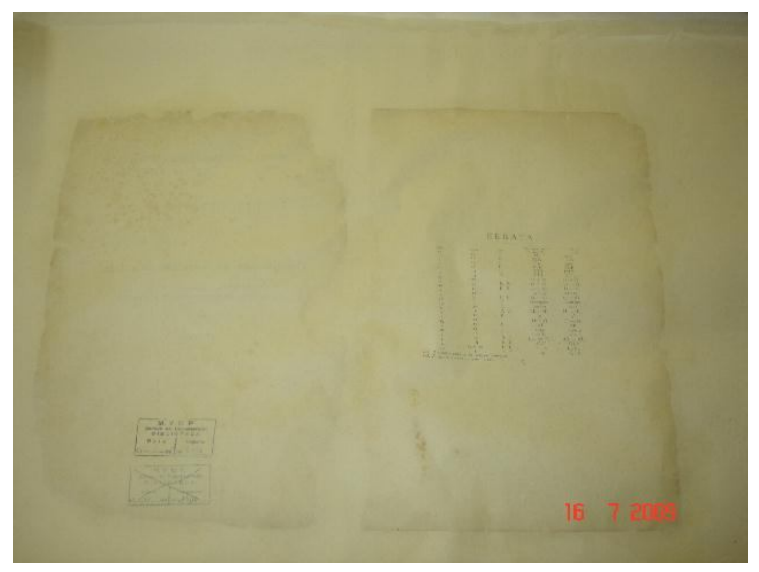

Figura 38: Resultado após o tratamento.

Após a secagem, as folhas foram refiladas utilizando-se um bisturi e uma régua, para retirar o excesso de papel deixado pela máquina. Essa técnica foi aplicada em $70 \%$ do livro e foi efetiva em seu objetivo, pois reintegrou áreas 
faltantes com papel na tonalidade próxima à do mesmo e lhe devolveu sua massa faltante.

\subsection{Tingimento do papel japonês}

O papel japonês ${ }^{4}$ é muito usado para fazer reparos em documentos, tanto em rasgos quanto em áreas que se encontram muito frágeis. Porém, como o seu tom é claro, ele fica bastante visível quando usado em documentos com a tonalidade mais escura, o que é o caso do livro objeto de estudo deste trabalho. Então, foi necessário fazer o tingimento do papel japonês para realizar os reparos.

"Tingir papeis é o ato de dar uma outra cor ao papel; para fazer isto, basta colocar as folhas em uma cuba com chá, café ou erva-mate, para dar a tonalidade desejada." (GRUN \& SANTOS, 2003, p. 19). Então, foi preparada a cuba com água deionizada e chá preto (uma trouxinha dissolvida) e em seguida se mergulhou o papel japonês, entre telas de nylon, na cuba.

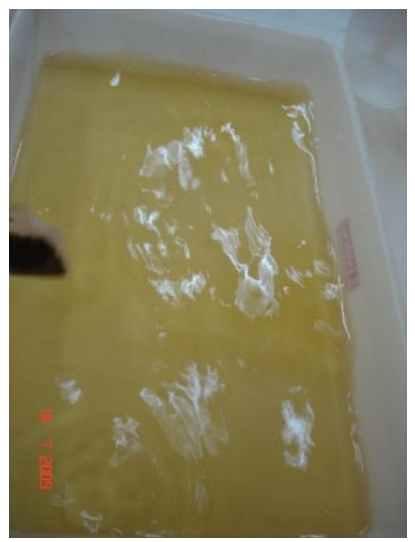

Figura 39: Cuba com água deionizada e chá preto.

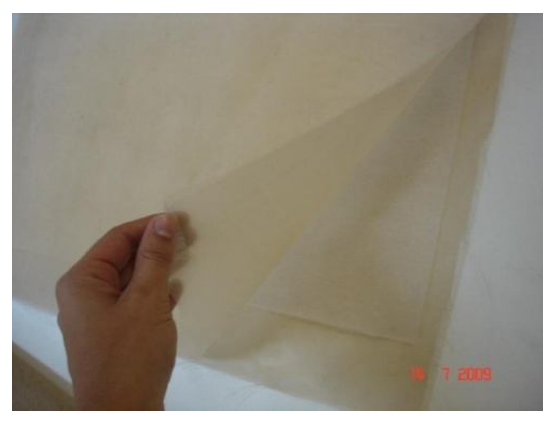

Figura 40: Papel japonês branco entre telas de nylon.

\footnotetext{
${ }^{4}$ Papel de baixa gramatura, resistente e livre de acidez.
} 
O papel japonês ficou imerso na água com chá durante três horas para atingir a tonalidade desejada. Quanto mais tempo dentro da cuba, mais escuro o papel fica.

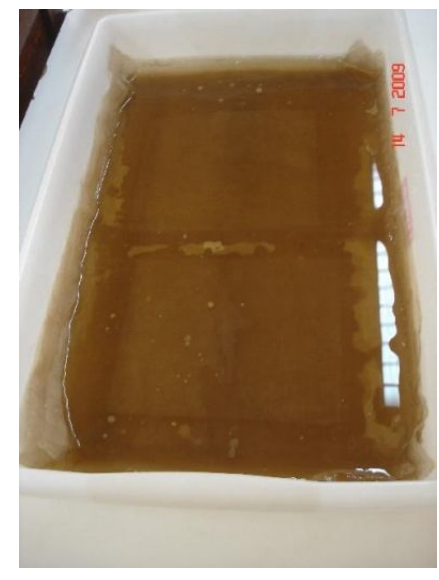

Figura 41: Papel japonês imerso em água com chá.

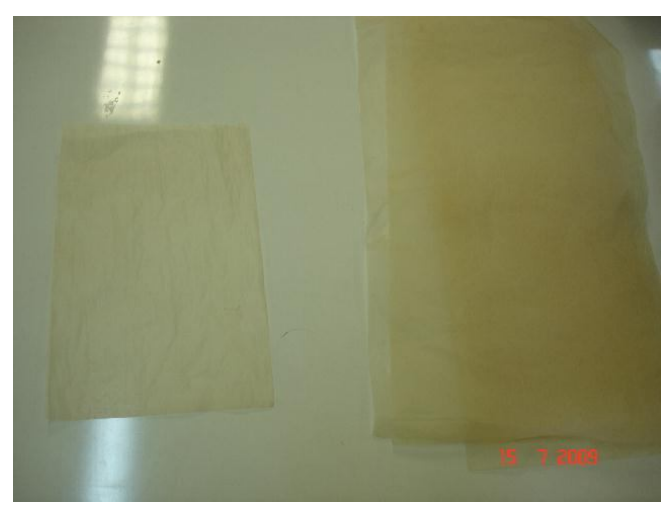

Figura 42: Papel japonês tingido.

Depois de retirar o papel, ele foi colocado na secadora. Depois de seco, pôde ser utilizado nos reparos do livro.

\subsection{Reparos com papel japonês}

Os reparos com papel japonês são feitos em rasgos e regiões de dobras de folhas como nas junções de páginas para formar cadernos. O papel japonês tem a finalidade de oferecer mais resistência às áreas frágeis e juntar partes rasgadas. Esses reparos sempre devem ser feitos no verso da folha por questão estética.

Quando se faz remendos ou reparos é fundamental observar o sentido das fibras do papel japonês e do papel a ser restaurado, pois elas devem obedecer o mesmo sentido.

Segundo Jaime Spinelli, para reparar áreas de dobradura e rasgos, deve-se proceder da seguinte maneira: 
Preparar uma tira de papel japonês adotando uma medida que exceda, no mínimo, $5 \mathrm{~mm}$ das bordas do rasgo ou dobra, esgarçando bem suas fibras de ambos os lados e aplicá-la com cola metilcelulose sobre as partes unidas do mesmo pelo verso da folha. Utilizando uma espátula e um pedaço de tela de nylon e de mata borrão, proceder à planificação do remendo. Deixar a folha remendada secar entre um sanduíche de tela, mata borrão e tábuas e sobre esta colocar alguns pesos. Este procedimento permitirá uma secagem plena da área recomposta, evitando a contração das fibras. (SPINELLI, 1997, p. 47)

Os reparos do livro foram feitos de acordo com a técnica de Jaime Spinelli, e o primeiro passo foi cortar o papel japonês. Para que as bordas ficassem esgarçadas, ele foi cortado com uma ponta de agulha, como mostra a Figura 43. Posteriormente, passou-se cola metilcelulose na parte desejada (pelo verso da folha), como mostra a Figura 44, e colada a tira de papel japonês.

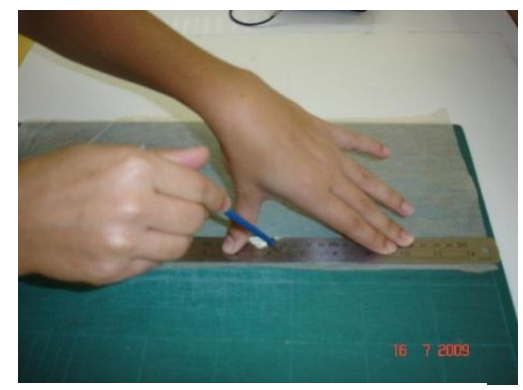

Figura 43: Corte no papel japonês com agulha.

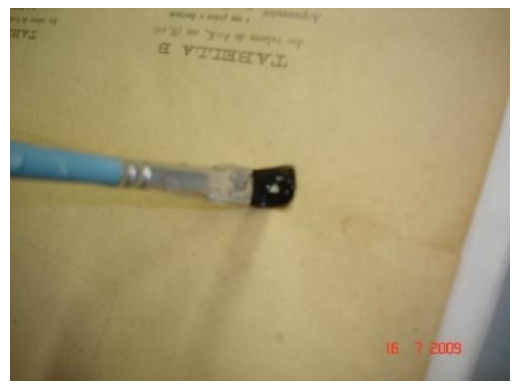

Figura 44: Aplicação da cola metilcelulose.

Em seguida, a folha foi colocada sobre um papel mata-borrão e, por cima da colagem, posicionou-se um pedaço de tela de nylon para planificar o remendo com uma espátula, como mostra a Figura 45.

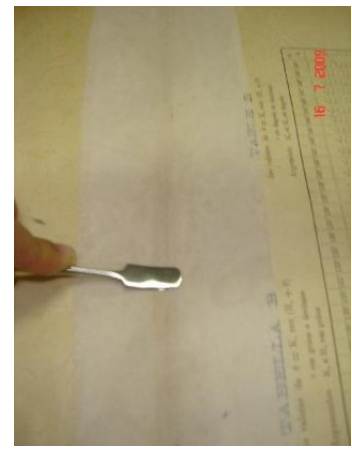

Figura 45: Planificação do remendo. 
Posteriormente, a folha secou entre um sanduíche de tela e mata-borrão e tábuas, sob pesinhos. $O$ excesso de papel japonês foi retirado com o bisturi.

Essa técnica foi usada em todas as folhas do livro, pois todas elas apresentavam rasgos ou dobras. Por fim, o resultado ficou muito bom, pois o papel japonês é fino e resistente, conseguindo assim dar resistência e qualidade estética ao documento. Como ele ainda estava tingido, ficou até menos visível a sua presença no suporte.

\subsection{Velatura}

"Velatura é o ato de colar sobre o verso de documentos executados sobre suporte de papel uma folha de papel japonês com o uso de cola metilcelulose, tendo o objetivo de conferir-Ihe maior resistência física." (SPINELLI, 1997, p. 77). Diante da conceituação de velatura feita por Jaime Spinelli, podemos concluir que ela oferece maior resistência ao suporte. Então, essa técnica foi aplicada nas folhas que ficam mais expostas, como as primeiras e as últimas, a fim de dificultar a sua degradação.

Para começar a preparar a velatura, observou-se o sentido das fibras do papel japonês para que ficassem compatíveis com o sentido das fibras do documento. Depois, com um borrifador, umedeceu-se uma folha de papel japonês sobre uma placa de papel acetato, como na Figura 46, e se esticou o papel japonês até o mesmo ficar completamente distendido, como na Figura 47.

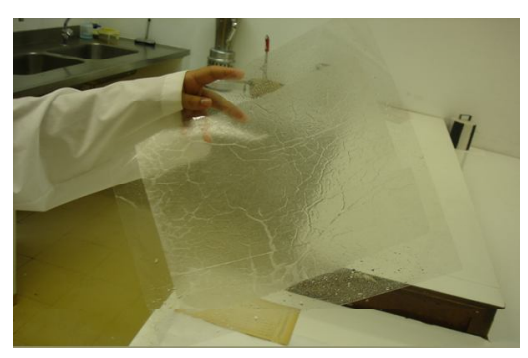

Figura 46: Papel japonês umedecido sobre placa de papel acetato.

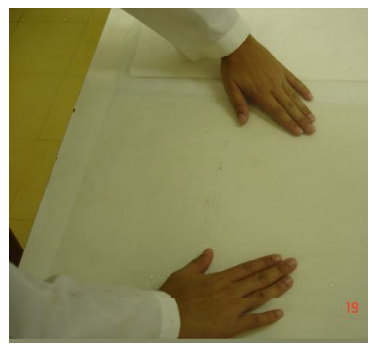

Figura 47: Papel japonês sendo esticado. 
Posteriormente, aplicou-se a cola metilcelulose usando um pincel macio, como na Figura 48, para, em seguida, colocar o documento com o verso voltado para o papel. Por fim, foi colocada uma tela de nylon e, utilizando um rolo de borracha, retirou-se o excesso de cola e o papel mata-borrão foi posto sobre a tela, como na Figura 49.

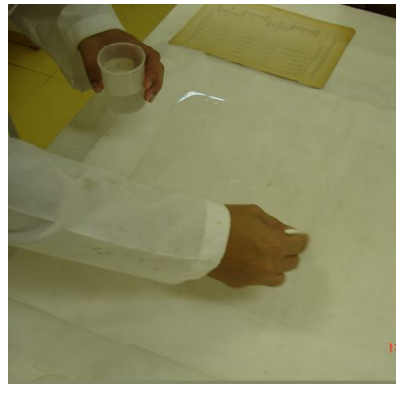

Figura 48: Aplicação de metilcelulose sobre 0 papel japonês.

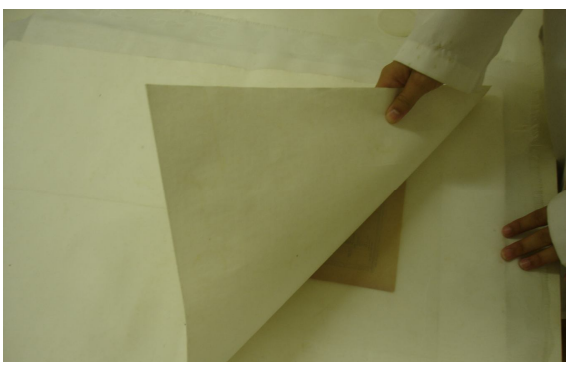

Figura 49: Velatura sob tela de nylon e mata-borrão.

Todo o material ficou entre tábuas e sob pesos. Deixou-se secar completamente, trocando o papel mata-borrão sempre que necessário. Depois que a folha fica seca, basta refilar o excesso de papel japonês.

\subsection{Enxerto}

"O enxerto consiste em recompor uma área faltante do papel com pedaços de papel similar em cor e textura. O papel mais utilizado para esta finalidade é o Ingris (sic) sempre na cor mais próxima do papel do livro." (GRUN \& SANTOS, 2003, p. 18). Assim, o enxerto foi realizado nas folhas que apresentavam perda de parte do suporte e que não passaram pela reconstituição mecânica na MOP. Como nos reparos e na velatura, os enxertos são feitos no verso da folha. 
Para dar início ao processo de enxerto, primeiramente se passou a cola metilcelulose na área a ser enxertada, como na Figura 50. Depois, aplicou-se um pedaço de papel feito na MOP com o tom próximo ao da folha do livro, como na Figura 51.

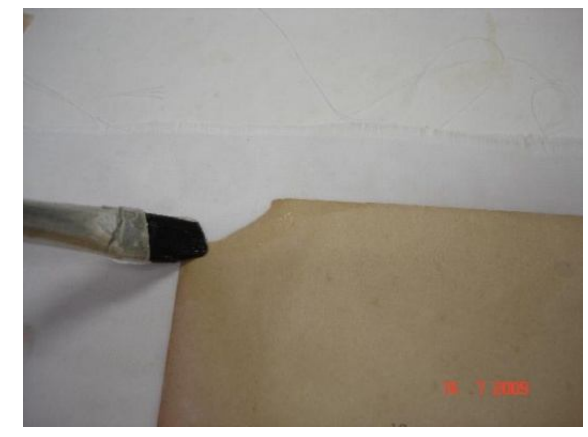

Figura 50: Aplicação de cola na área a ser enxertada.

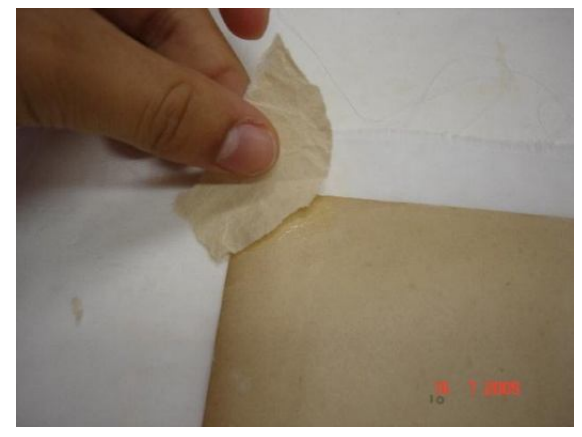

Figura 51: Aplicação do papel de enxerto.

Quando a cola metilcelulose amolecer o papel usado para o enxerto, inicia-se o desbastamento das bordas para que ele fique no formato da parte faltante, como na Figura 52. Então, colocou-se um pedaço de tela de nylon sobre o material para, com uma espátula, alisar a parte colada, visando à sua completa adesão. Por fim, secou-se a cola com uma espátula térmica, como na Figura 53, e se refilou o excesso de papel com um bisturi.

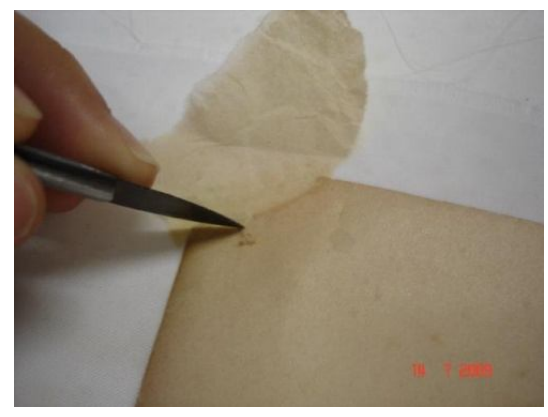

Figura 52: Desbastamento do papel de enxerto.

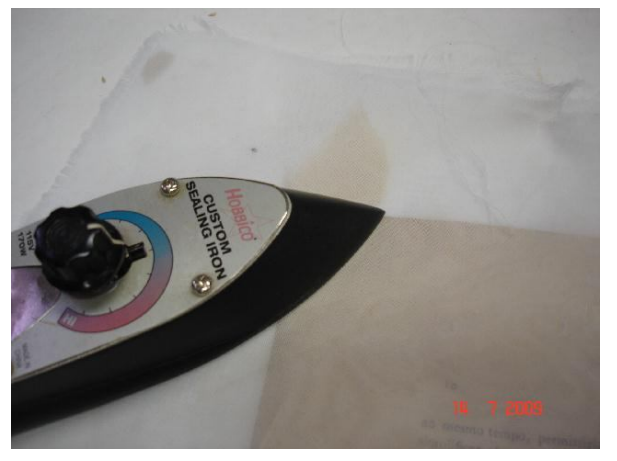

Figura 53: Secagem com espátula térmica. 


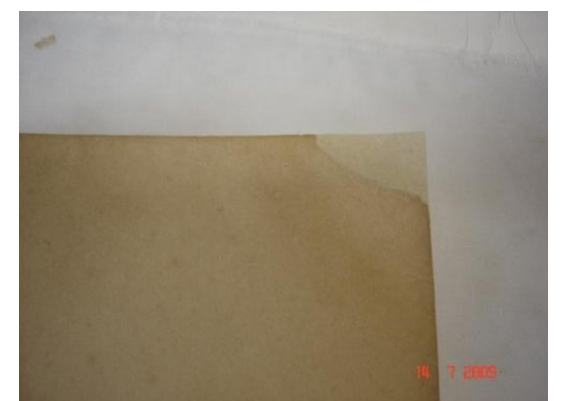

Figura 54: Resultado final da área enxertada.

\subsection{Preenchimento de furos com polpa de papel}

O livro sofreu ataque de brocas e ficou cheio de furos. Alguns furos foram ocasionados pelo processo de higienização, na tiragem de pontos de ferrugem. Então, tornou-se necessário preencher furos das folhas que não passaram pela reconstituição na MOP.

O primeiro passo foi amassar, usando um pincel duro, um pouco da polpa de papel (a mesma usada na reintegração mecânica), junto com metilcelulose e água deionizada, sobre um pedaço de mármore, até a mistura ficar homogênea, como na Figura 55.

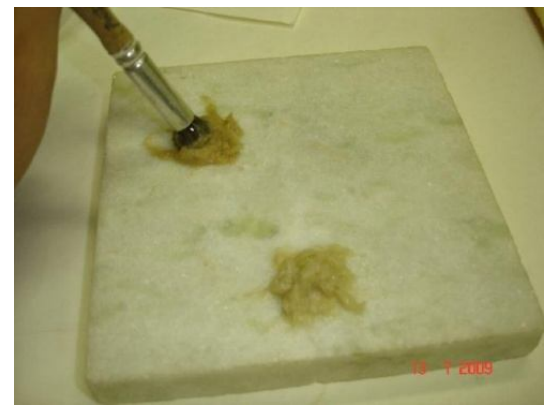

Figura 55: Polpa de papel com metilcelulose.

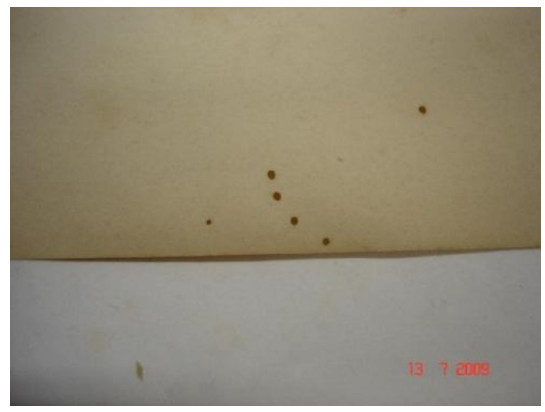

Figura 56: Furos ocasionados por ataque de brocas. 
Após preparar a polpa, usando uma agulha, preencheram-se os furos delicadamente colocando $o$ tanto de polpa necessário para que não ficasse muito grosso nem muito fino, ou seja, procurando atingir a mesma gramatura do papel (Figura 57). Em seguida, a aplicação de polpa foi fixada com uma espátula sobre um pedaço de tela de nylon (Figura 58).

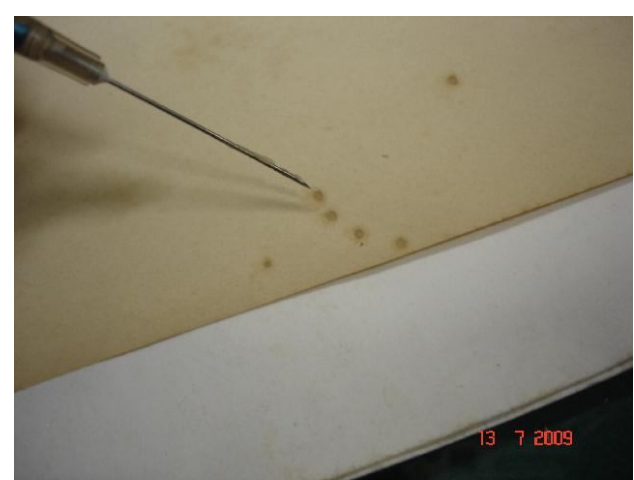

Figura 57: Aplicação de polpa de papel em furos.

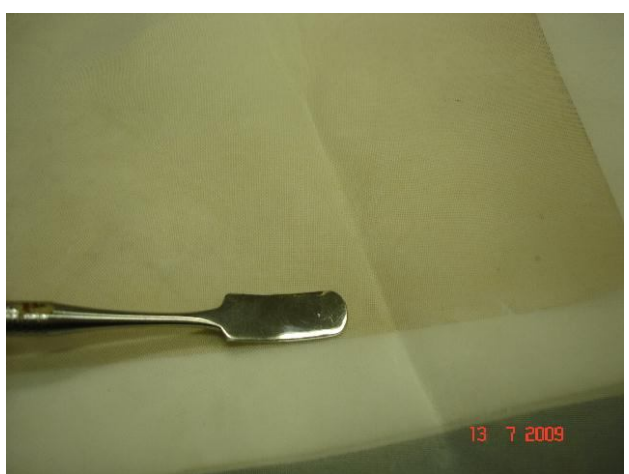

Figura 58: Espátula fixando a aplicação de polpa.

Quando a aplicação de polpa já estava fixada, o passo seguinte foi secar a polpa aplicada com a espátula térmica e o resultado está ilustrado na Figura 59.

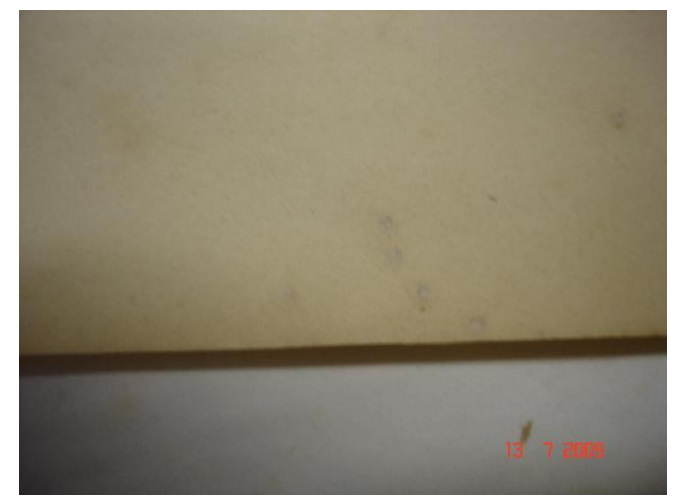

Figura 59: Resultado após o preenchimento. 


\subsection{Nova costura}

Depois que as folhas do livro foram todas restauradas, o passo seguinte foi montá-las em cadernos para posteriormente costurá-los.

Como o livro era muito fino, escolheu-se fazer a costura espanhola, sem cordão de segurança.

Foram feitos seis leves serroteados na lombada do livro para poder penetrar a agulha com a linha. Depois a costura foi arranjada à mão, com linha de algodão.

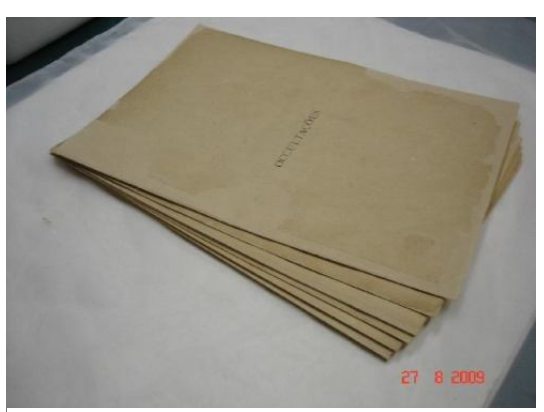

Figura 60: Cadernos montados.

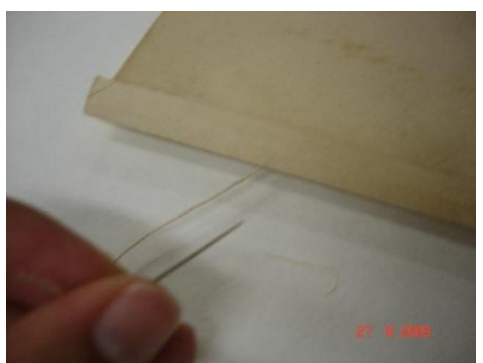

Figura 61: Costura com agulha e linha de algodão.

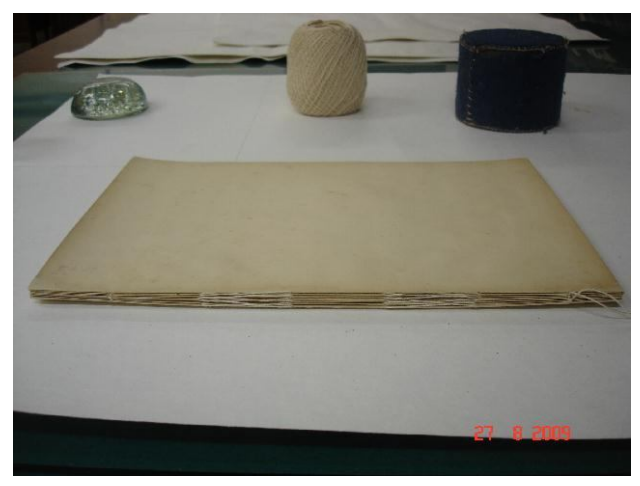

Figura 62: Costura pronta. 


\section{RESULTADO FINAL}

Após o miolo ser completamente restaurado, sua ficha de tratamento (ANEXO B) deve ser preenchida. Essa ficha tem a finalidade de documentar todo o processo de restauração que o documento sofreu, inclusive com fotografias. Quando tudo está devidamente concluído, o miolo é mandado para a encadernação.

A encadernação do livro foi feita por outro restaurador, que também deve seguir os princípios da restauração, documentando tudo que desempenha na capa.

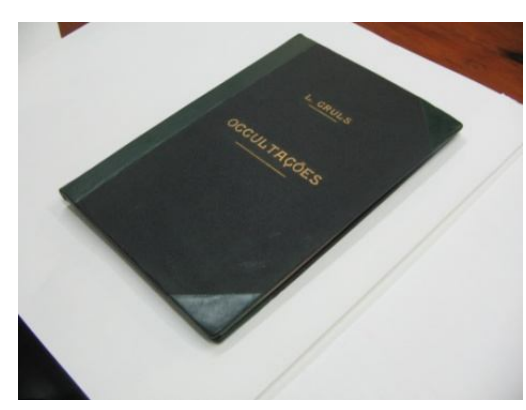

Figura 63: Capa restaurada

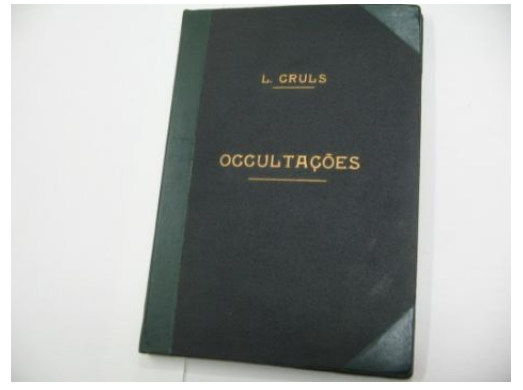

Figura 64: Capa restaurada - 2

As figuras 63 e 64 ilustram o resultado da restauração da capa do livro e pode-se observar que a originalidade dela foi preservada, como material, estilo de douração e cor. Nota-se que a capa foi aproveitada e não substituída, para que um dos princípios mais importantes da restauração fosse seguido, que é o do restabelecimento da obra e não a sua cópia. O material acrescentado ao suporte é facilmente identificável, porém harmonioso ao conjunto. Os buracos foram preenchidos e a cor, tanto do material que reveste a capa quanto da douração, foram revigoradas.

O estilo de encadernação foi levemente modificado, ou seja, a encadernação não possuía cantos e passou a possuir. Porém foi necessário acrescentá-los porque a área aonde os cantos foram adicionados estava muito danificada e necessitava de uma maior proteção, que foi conseguida dessa forma. Mas como já foi dito anteriormente, todo o material acrescentado à capa 
é facilmente identificável, não causando um falso histórico e sim devolvendo a utilidade da obra e sua maior proteção.

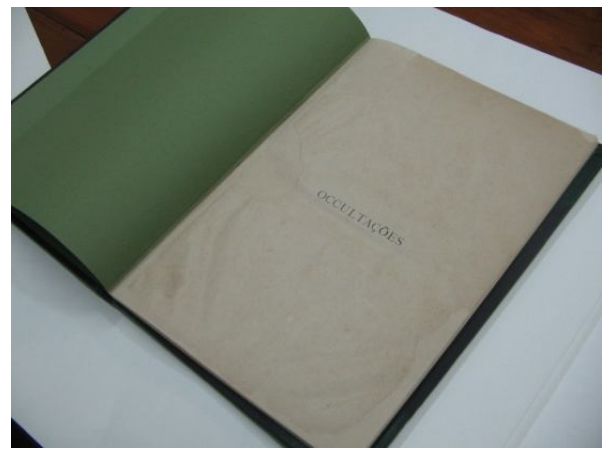

Figura 65: Miolo restaurado

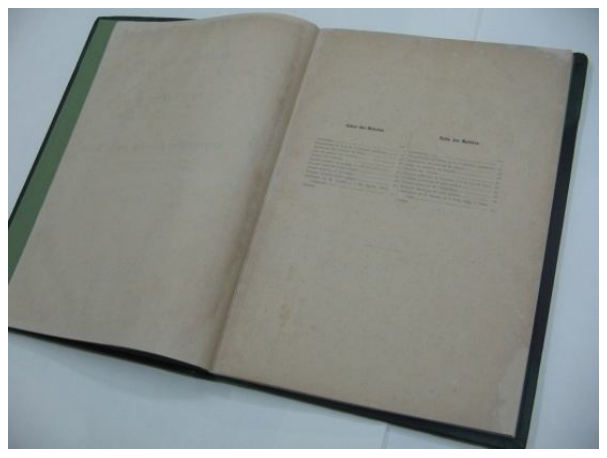

Figura 66: Miolo restaurado - 2

As partes faltantes das folhas do miolo do livro foram preenchidas com o papel da mesma gramatura da folha e com a tonalidade próxima à mesma. Os rasgos foram remendados (com o papel japonês), as manchas causadas por fita adesiva foram retiradas, as folhas que estavam frágeis foram reforçadas (com a velatura), a acidez foi controlada (com o banho) as sujeiras foram removidas (com a higienização e o banho) e a costura foi restabelecida. Assim como na capa, os materiais acrescentados ao miolo são facilmente identificáveis e harmônicos ao conjunto.

A restauração do miolo do livro devolveu o seu estado completo e sua utilidade. Seu conteúdo foi mantido e suas características preservadas. Portanto o processo de restauração conseguiu a sua finalidade que é de reparar o documento - possibilitando a sua reutilização -, e não eliminar suas peculiaridades históricas. 


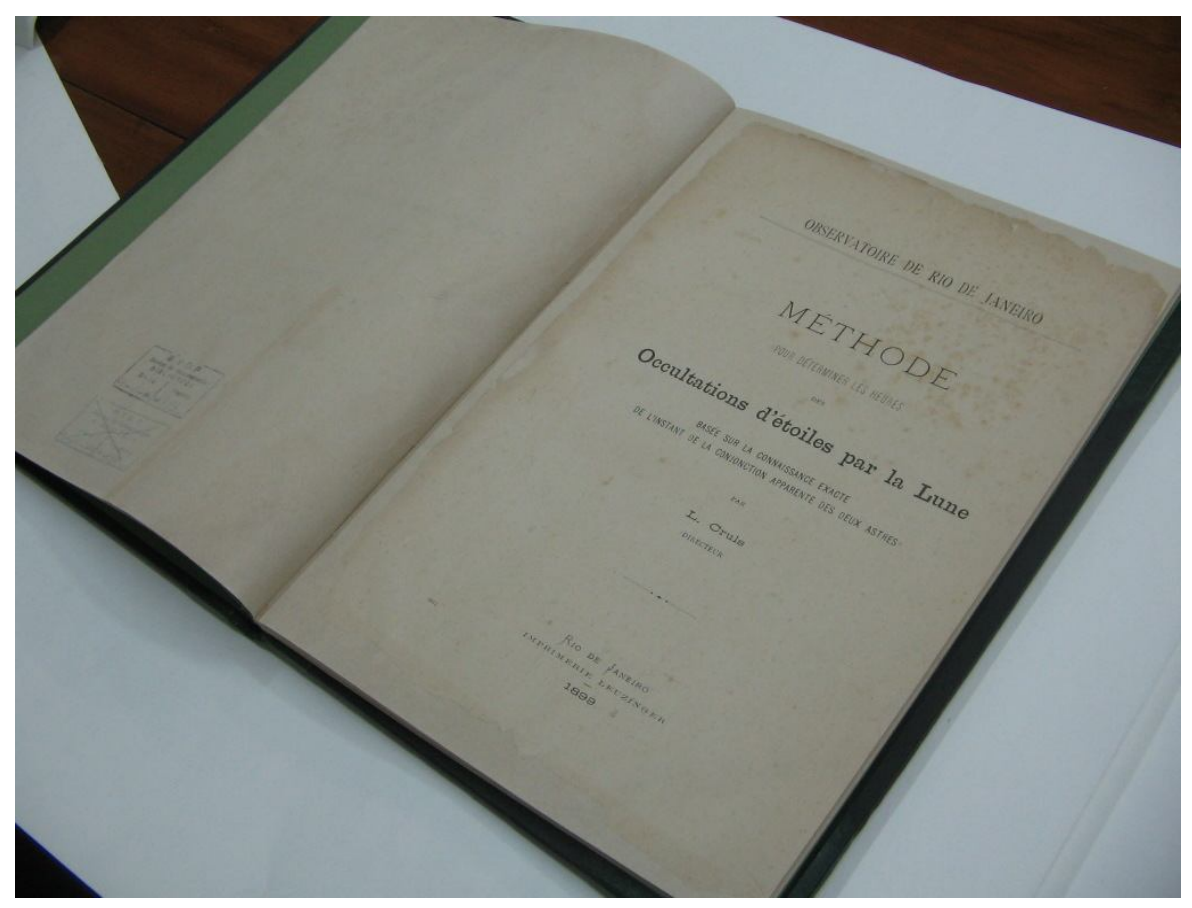

Figura 67: Miolo restaurado - 3 


\section{CONCLUSÃO}

Quando um livro está desgastado, sujo, com sinais de ataques de insetos, significa que o mesmo foi tratado com descaso, deixando que a ação dos agentes não imediatos tomasse conta do mesmo. Mas também existem os agentes imediatos, que são devastadores, de difícil previsão e seus danos são quase sempre irreversíveis, necessitando de socorro rápido para evitar a perda de informação e uma política de preservação eficaz. A preservação e conservação de documentos com suporte em papel devem ser priorizadas, pois, se forem eficientes, evitarão a degradação do papel e, consequentemente, a perda de informação. A restauração é a última tentativa de salvar o documento e necessita de mão-de-obra especializada e cara, por isso deve ser evitada ao máximo, buscando preservar e conservar para não haver a necessidade de restaurar.

Para realizar um processo de restauração, deve-se seguir uma série de princípios que visam, em geral, a manter as raízes do objeto, ou seja, conservar suas características históricas, artísticas e materiais. É importante salientar que toda intervenção feita deve ser sutil, identificável e reversível, buscando restabelecer o objeto e permitindo que uma futura intervenção seja viável.

Várias técnicas de restauração realizadas no CEDOC foram abordadas, mostrando seus processos através de fotos e descrições. Os princípios da restauração foram seguidos durante os processos, ou seja, o objeto foi revitalizado e restabelecido para que pudesse ser usado novamente e sem perder seus traços históricos e originalidade.

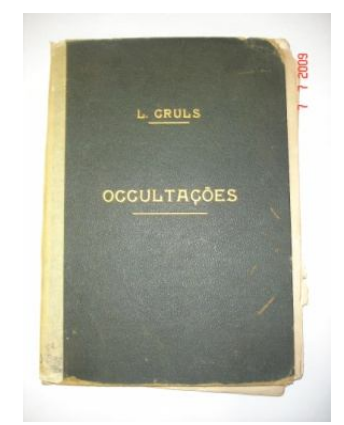

Figura 68: Capa antes da restauração.

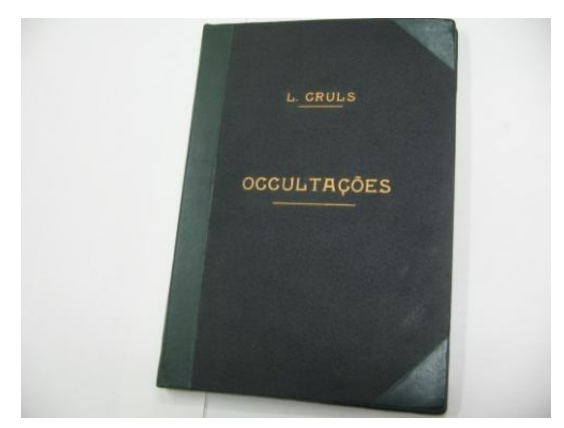

Figura 69: Capa após a restauração. 


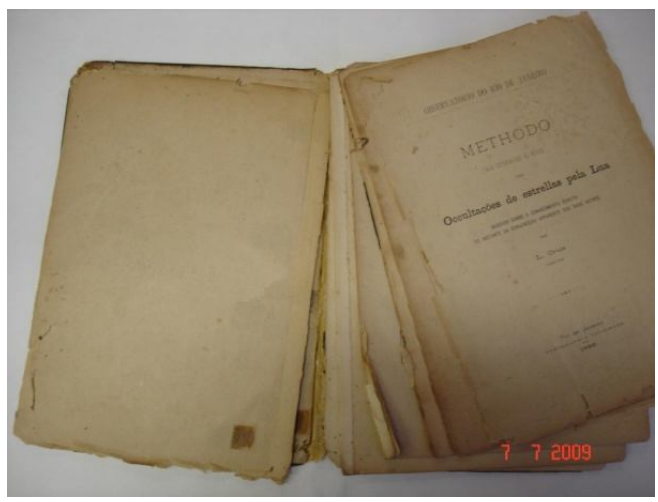

Figura 70: Miolo antes da restauração.

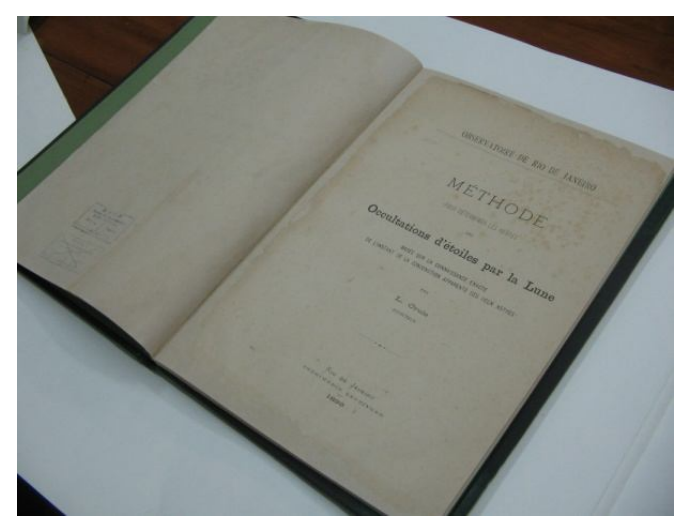

Figura 71: Miolo após a restauração. 
ANEXOS 
ANEXO A

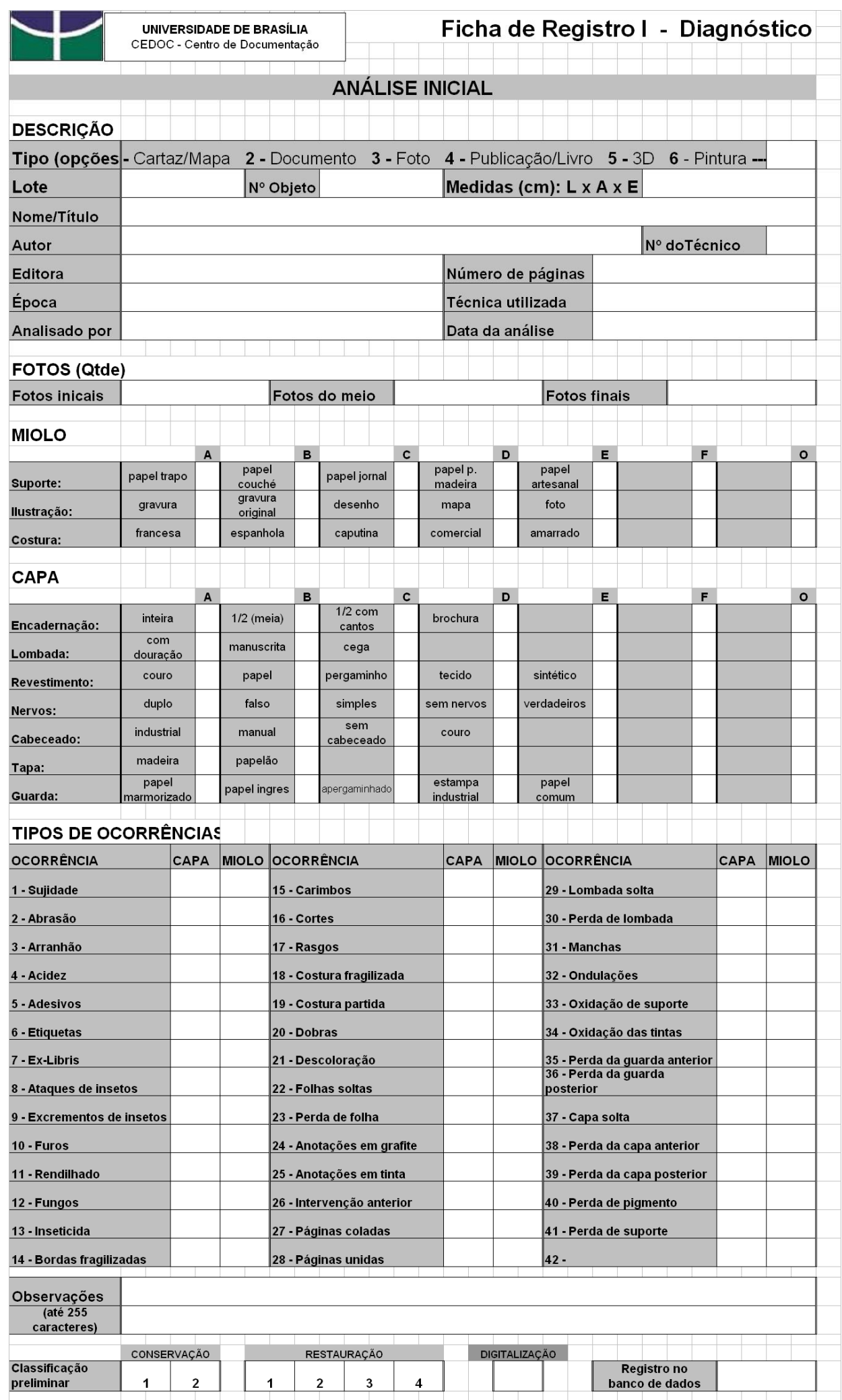


ANEXO B

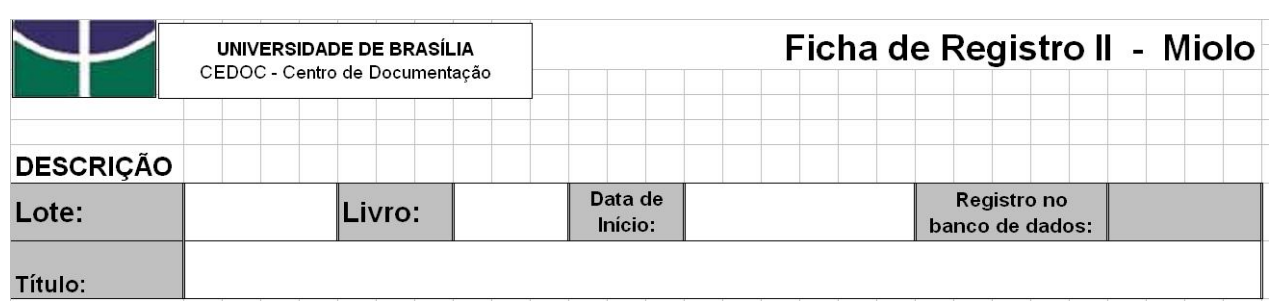

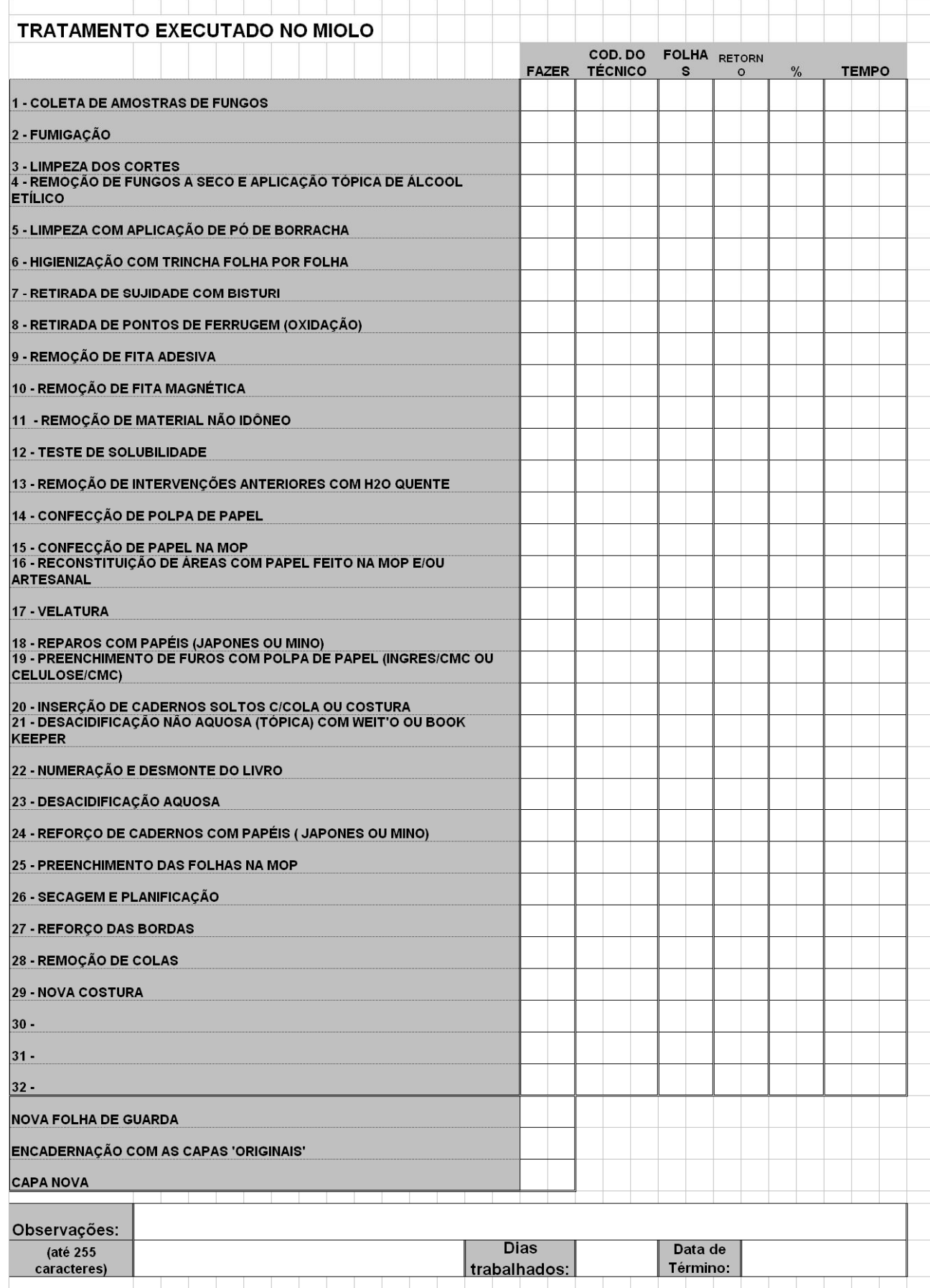




\section{REFERÊNCIAS}

BECK, Ingrid. Manual de conservação de documentos. Rio de Janeiro: Ministério da Justiça/Arquivo Nacional, 1985.

BRANDI, Cesare. Teoria da restauração. Cotia/SP: Ateliê Editorial, 2004. (Artes \& Ofícios, 5).

CAMARGO, A. M. A., BELLOTTO, H. L. (coord.) Dicionário de terminologia arquivística. São Paulo: AAB, 1996.

CASSARES, Norma Cianflone. Como fazer conservação preventiva em arquivos e bibliotecas. São Paulo: Arquivo do Estado e Imprensa Oficial, 2000. (Projeto Como Fazer, 5).

CUNHA, Murilo B.; CAVALCANTE, Cordélia R. O. Dicionário de Biblioteconomia e Arquivologia. Brasília: Briquet de Lemos Livros, 2008.

FEILDEN, Bernard M. Os princípios da conservação. Correio da UNESCO, 1981 , p. $27-28$.

GRUN, Renata C.; SANTOS, Jussara P. Restauração de documentos e encadernação de livros: noções básicas. Porto Alegre: UFRGS, 2003.

LE COADIC, Yves-François. A ciência da informação. $2^{\underline{a}}$ ed. Brasília: Briquet de Lemos, 2004.

PEREIRA, Mariana F. C.S. Desacidificacao aquosa da celulose em documentos gráficos (banhos restauradores em papel). Revista Brasileira de Arquiometria, Restauração e Conservação, v. 1, n. 5, [2007?], p. 261-264.

SARACEVIC, T. Ciência da Informação: origem, evolução e relações, in Perspectivas em Ciência da Informação, v. 1, n. 1, p. 41-62, jan./jun. 1996.

SPINELLI JUNIOR, Jayme. A conservação de acervos bibliográficos e documentais. Rio de Janeiro: Fundação Biblioteca Nacional, 1997. 
VIOLET-LE-DUC, Eugène E. Restauração. Cotia: Ateliê Editorial, 2000. (Artes \& Ofícios, 1).

ZÚÑIGA, Solange Sette G. de. A importância de um programa de preservação em arquivos públicos e privados. Registro: Revista do Arquivo Público Municipal de Indaiatuba, Indaiatuba, Ano 1, v. 1, n. 1, p. 71-89, 2002. 
